\title{
A systematic reassessment and paleogeographic review of fossil Xenarthra from Peru
}

Réévaluation systématique et révision paléogéographique des Xénarthres fossiles du Pérou

Reevaluación sistemática y revisión paleogeográfica de los Xenartros del Perú

\section{François Pujos and Rodolfo Salas}

\section{CpenEdition}

\section{Journals}

Electronic version

URL: http://journals.openedition.org/bifea/5746

DOI: 10.4000/bifea.5746

ISSN: 2076-5827

\section{Publisher}

Institut Français d'Études Andines

\section{Printed version}

Date of publication: 1 August 2004

Number of pages: 331-377

ISSN: 0303-7495

\section{Electronic reference}

François Pujos and Rodolfo Salas, « A systematic reassessment and paleogeographic review of fossil Xenarthra from Peru », Bulletin de I'Institut français d'études andines [Online], 33 (2) | 2004, Online since 08 April 2004, connection on 02 December 2020. URL : http://journals.openedition.org/bifea/5746 ; DOI : https://doi.org/10.4000/bifea.5746

\section{(ब) $\Theta \Theta$}

Les contenus du Bulletin de l'Institut français d'études andines sont mis à disposition selon les termes de la licence Creative Commons Attribution - Pas d'Utilisation Commerciale - Pas de Modification 4.0 International. 
Bull. Inst. fr. études andines

2004, 33 (2): 331-377

\title{
A SYSTEMATIC REASSESSMENT AND PALEOGEOGRAPHIC REVIEW OF FOSSIL XENARTHRA FROM PERU
}

\author{
François PUJOS*, Rodolfo SALAS ${ }^{* *}$
}

\begin{abstract}
A revision of Peruvian Xenarthra and the discovery of new specimens have increased our knowledge of the Order in this country. About thirty sites from three geographic regions, Amazonian Forest, the Andes, and the coast have yielded Xenarthra in Peru. The only well known Pre-Pleistocene Xenarthra is Thalassocnus from the Mio-Pliocene of the Pisco Formation. Pleistocene Phyllophaga (Megatheriidae, Nothrotheriidae, Mylodontidae, and Megalonychidae) and Cingulata (Pampatheriidae and Glyptodontidae) are rare in the Amazonian forest region, abundant in the coastal region and are particularly frequent in the Andes (between 2500 and 4500 meters). Cingulata are not as diverse and are represented only byHolmesina cf. paulacouto $i$ along the coast and Glyptodon clavipes in the Andes. The mylodontid Glossotherium sp. is recognized in the entire Peruvian coast and the scelidothere Scelidodon chiliensis is abundant in both the Andes and northern coast region. Pleistocene nothrotheres are found only in the Amazonian forest region (Nothropus priscus in Río Acre). Megatheriidae are well diversified and have an extended geographic range. The tropical genus Eremotherium (E. laurillardi) is present on the northern coast and is possibly represented in Amazonia by a gigantic form. The temperate genus Megatherium is represented in Peru by a small-sized, quadrupedal, and browser of the Andean linage of the subgenus $M$. (Pseudomegatherium), which includes $M$. (P.) tarijense, $M$. $(P$.) elenense, $M$. (P.) urbinai, and new species from the northern Andes. Large species of sloths such as Megatherium (Megatherium) americanum, Lestodon sp., and Scelidotherium leptocephalum that are typical of the Argentinian Pampas are absent in Peru. A peculiar new megalonychid was discovered in the north coast region (Cupisnique desert) and in the Andes near Lake Titicaca at Casa del Diablo cave. ${ }^{14} \mathrm{C}$ dating indicates that most of fossil mammals in Peru are Lujanian in age. Along the coast and probably in Amazonia, Xenarthra are found in open
\end{abstract}

* IFEA: Institut Français d'Études Andines, Casilla 18-1217, Av. Arequipa 4595, Lima 18, Perú \& MNHN: Département Histoire de la Terre, UMR 8569 du CNRS, Muséum national d'Histoire naturelle, 8 rue Buffon, 75005 Paris, France. E-mail: fpujos@yahoo.fr

${ }^{* *}$ MUSM: Departamento de Paleontología de Vertebrados, Museo de Historia Natural de la Universidad Nacional Mayor de San Marcos, Av. Arenales 1256, Apdo. 14-0434, Lima 14, Perú. E-mail:rodsalasgis@yahoo.com 
localities, in contrast to the Andean region in which most specimens are preserved in caves. In Peru, and all over South America, large Xenarthra did not survive beyond the beginning of the Holocene.

Key words: Xenarthra, Peru, Cenozoic, Quaternary, Systematic revision, Paleogeography.

\section{RÉÉVALUATION SYSTÉMATIQUE ET RÉVISION PALÉOGÉOGRAPHIQUE DES XÉNARTHRES FOSSILES DU PÉROU}

\section{Résumé}

La révision des Xénarthres péruviens ainsi que la découverte de nouveaux spécimens permet d'étendre la connaissance de cet ordre sur ce territoire. Une trentaine de sites de la forêt amazonienne, des Andes et de la Côte ont révélé la présence de Xénarthres au Pérou. Thalassocnus, du mio-pliocène de la Formation Pisco, est le seul Xénarthre pré-pléistocène bien connu. Les Phyllophaga (Megatheriidae, Nothrotheriidae, Mylodontidae et Megalonychidae) et les Cingulata (Pampatheriidae et Glyptodontidae) pléistocènes sont rares dans la forêt amazonienne, mais sont abondants sur la côte et extrêmement fréquents dans les Andes (entre 2500 et 4500 mètres d'altitude). Les Cingulata sont faiblement diversifiés et représentés uniquement sur la côte par Holmesina cf. paulacoutoi et dans les Andes par Glyptodon clavipes. Le mylodontide Glossotherium sp. est reconnu sur l'ensemble de la côte péruvienne alors que le scelidotheriine Scelidodon chiliensis est abondant dans les Andes ainsi que sur la côte nord. Les nothrotheridés pléistocènes sont uniquement localisés en forêt amazonienne (Nothropus priscus de Río Acre). Les Megatheriidae sont géographiquement particulièrement bien représentés et diversifiés. Le taxon tropical Eremotherium (E. laurillardi) est présent sur la côte nord et peut-être également par une forme de grande taille en Amazonie. Le genre tempéré Megatherium est représenté au Pérou par une lignée andine présentant des formes de petite taille, quadrupèdes et plutôt brouteuses (Megatherium (Pseudomegatherium)). Cette lignée regroupe $M$. (P.) tarijense, $M$. (P.) elenense, $M$. (P.) urbinai ainsi qu' une espèce inédite du nord des Andes. Les taxons de grande taille tels que Megatherium (Megatherium) americanum, Lestodon sp. et Scelidotherium leptocephalum, typiques des vastes pampas d'Argentine, sont absents au Pérou. Un nouveau mégalonychidé très particulier vient d'être découvert sur la côte nord (désert de Cupisnique) ainsi que dans les Andes à proximité du lac Titicaca (grotte de Casa del Diablo). Des datations ${ }^{14} \mathrm{C}$ traduisent que la majorité des mammifères fossiles découverts au Pérou sont d'âge Lujanien. Sur la côte et probablement également en Amazonie, les Xénarthres proviennent de localités à ciel ouvert mais pas de grottes comme dans les Andes. Au Pérou comme dans l'ensemble de l'Amérique du Sud, les grands Xénarthres se sont éteints au début de l'Holocène.

Mots clés :Xénarthres, Pérou, Cénozö̈que, Quaternaire, révision systématique, paléogéographie.

\section{REEVALUACIÓN SISTEMÁTICA Y REVISIÓN PALEOGEOGRÁFICA DE LOS XENARTROS DEL PERÚ}

\section{Resumen}

Una revisión de los xenartros peruanos, asícomo el descubrimiento de nuevos especímenes, han incrementado nuestro conocimiento sobre el Orden en este país. Cerca de treinta localidades pertenecientes a tres regiones geográficas (el bosque amazónico, los Andes y la costa) han brindado restos de Xenartros en el Perú. Thalassocnus, del Mio-Plioceno de la Formación Pisco, es el único Xenartro pre-pleistocénico bien conocido. Los Phyllopaga (Megatheriidae, 
Nothrotheriidae, Mylodontidae y Megalonychidae) y Cingulata (Pampatheriidae y Glyptodontidae) pleistocénicos son escasos en la región amazónica, abundantes en la costa y muy frecuentes en los Andes (entre 2500 y 4500 metros de altitud). Los Cingulata no son tan diversos y están representados solo por Holmesina cf. paulacoutoi a lo largo de la costa norte y Glyptodon clavipes en los Andes. El milodóntido Glossotherium sp. es reportado en toda la costa peruana y el escelidoterino Scelidodon chilensis es abundante en los Andes y en la costa norte. Notrotéridos pleistocénicos solo han sido hallados en la región amazónica (Nothropus priscus de Río Acre). Por su parte, los Megatheriidae están bien diversificados y ampliamente distribuidos geográficamente. La forma tropical Eremotherium (E. laurillardi) está registrada en la costa norte y posiblemente representada en la región amazónica por un espécimen gigantesco. El género Megatherium de clima templado está representado en el Perú por un linaje exclusivamente andino presentando formas de tamaño pequeño, cuadrupedos y con tendencia a pastar perteneciente al subgénero $M$. (Pseudomegatherium) e incluye a $M$. (P.) tarijensis, $M$. (P.) elenense, $M$. $(P$. urbinai y una nueva especie de la zona norandina. Las grandes especies de perezosos como $M$. (Megatherium) americanum, Lestodon sp., y Scelidotherium leptocephalum descubiertos en las Pampas Argentinas no han sido reportados en el Perú. Un nuevo megaloníquido muy peculiar fue descubierto en la costa norte (desierto de Cupisnique) y en los Andes, cerca al lago Titicaca (cueva casa del diablo). Dataciones relizadas con ${ }^{14} \mathrm{C}$, así como la asociación faunística indican que la mayoría de los mamíferos fósiles del Perú pertenecen al Lujanense. A lo largo de la costa y probablemente en la Amazonía, los Xenarthra han sido descubiertos en localidades abiertas, en contraste con la región andina donde la mayor parte de los especímenes se conservaron en cuevas. En el Perú y en toda Sudamérica los grandes Xenartros se extinguen al comienzo del Holoceno.

Palabras claves: Xenarthra, Perú, Cenozoico, Cuaternario, revisión sistemática, paleogeografía.

Tertiary and Quaternary fossil land mammals are particularly well-represented in Argentina, Brazil, Bolivia, Colombia, and Ecuador. In contrast, our knowledge of Peruvian fossil land mammals is far from satisfactory. The presence of fossil mammals in Peru has been known for a century and several authors such as Gervais (1855), Nordenskiöld (1905; 1908), Lisson (1912), Spillmann (1949), Churcher (1959; 1962; 1965), Hoffstetter (1970; 1986), McNeish et al. (1970), Cardich (1973), Marshall et al. (1983; 1984), Frailey (1986), Muizon \& McDonald (1995), Pujos (2000; 2001; 2002b), Salas et al. (2003), Pujos \& Salas (2002; 2004) and Pujos et al. (2004), have all contributed to our understanding of fossil mammals in Peru. Hoffstetter $(1970 ; 1986)$ and Marshall et al. $(1983 ; 1984)$ provided reviews of South American mammals.

Xenarthrans represent an original and significant group of the endemic South American mammal fauna. This peculiar Order is represented by the Phyllophaga (= Tardigrada, sloths), the Vermilingua (= anteaters), and the Cingulata (= armadillos, glyptodonts, and pampatheres). They are present in South America since the Paleocene and are endemic to the Americas, with two exceptions, in Antarctica (Vizcaíno \& Scillato-Yané, 1995) and West Indies (MacPhee \& Iturralde-Vinent, 1994).

The aim of this work is to actualize the Xenarthran fauna of Peru. The material presented includes a revision of the specimens previously cited and described by earlier authors and to summarize new Xenarthran material recently discovered. About thirty 
Peruvian localities with fossil Xenarthran assemblages will be presented. Information collected for each locality includes the geology, stratigraphy, taphonomy, and age. A systematic study of all the specimens of known geographic origin and age from Peru is provided for both the Phyllophaga (i.e. [Megatheriidae + Nothrotheriidae + Megalonychidae + Mylodontidae]) and Cingulata (i.e. [Pampatheriidae + Glyptodontidae]). The distribution of members of each family in each of the three main regions in the country, the coastal area, the Andes, and/or the Amazonian forest is considered. Geographical range, diversity, intraspecific variations, and adaptations will be also discussed. The chronology of South American Land Mammal Ages (SALMA) corresponds to the one proposed by McKenna \& Bell (1997).

\section{INSTITUTIONAL ABBREVIATIONS}

FMNH - Field Museum of Natural History, Chicago, USA

GRD-NPS - National Park Service - Geologic Resources Division, Denver, USA HDD - Huaca del Dragón, Trujillo, Peru

IFEA - Institut Français d'Etudes Andines, Lima, Peru

INC - Instituto Nacional de la Cultura del Perú, Lima, Peru

IPGQ - Institut de Paléontologie et de Géologie du Quaternaire, Bordeaux, France

IPH - Institut de Paléontologie Humaine, Paris, France

LACM - Natural History Museum of Los Angeles County, Los Angeles, USA

MAE - Ministère des Affaires Etrangères, Paris, France

MLH - Casa Museo de La Huaca "Elba Aranda de Sarango", Piura, Peru

MLP - Museo de La Plata, La Plata, Argentina

MNHN - Muséum national d'Histoire naturelle, Paris, France

MUSM - Museo de Historia Natural de la Universidad Mayor de San Marcos, Lima, Peru

NMR - Swedish Museum of Natural History, Stockholm, Sweden

ROM - Royal Ontario Museum, Toronto, Canada

SMNK - Staatliche Museum für Naturkunde, Karlsruhe, Germany

UF - Florida Museum of Natural History - University of Florida, Gainesville, USA

UNALM - Universidad Nacional Agraria La Molina, Lima, Peru

UNI - Universidad Nacional de la Ingeniería, Lima, Peru

UNMSM - Facultad de Geología de la Universidad Nacional Mayor de San Marcos, Lima, Peru

\section{MIO-PLIOCENE SITES}

Mio-Pliocene non-marine formations are rare in Peru (Fig. 1). Three MioPliocene mammal bearing sites are recognized from the Amazonian forest and one from the Peruvian Coast. 


\section{Material}

Several complete or sub-complete specimens (see Muizon \& McDonald, 1995; McDonald \& Muizon, 2002; Muizon et al., 2003; 2004) with the following types MNHN SAS 734 (T. natans), MNHN SAS 1615 (T. littoralis), SMNK PAL 3814 (T. carolomartini), and MUSM 228 ( $T$. antiquus).

Hoffstetter (1968) reported the existence of a marine vertebrate fauna from the Pisco formation. "This fauna has yielded numerous remains of a Xenarthra which shares features with both Planops and Pseudoprepotherium" (Hoffstetter, 1970: 976; Marshall et al., 1983: 55). Muizon latter collected several complete specimens in Pisco formation. Muizon \& McDonald (1995), McDonald \& Muizon (2002), and Muizon et al. (2003; 2004), have documented the existence of a possible nothrothere lineage: Thalassocnus antiquus (late Miocene from Aguada de Lomas) - T. natans (late Miocene from SudSacaco) - T. littoralis (early Pliocene from Sud-Sacaco) - T. carolomartini (early-late Pliocene from Sacaco). Thalassocnus is interpreted to have fed in a marine environment (McDonald \& Muizon, 2002) and is associated with marine mammals, marine birds, crocodiles, fishes, and chondrichthians. It is the first Phyllophaga to be recognized as having aquatic or semi-aquatic habits (Muizon \& McDonald, 1995).

\section{PLEISTOCENE SITES}

Pleistocene mammals are relatively common in Peru (Fig. 1). Hoffstetter (1970, 1986) and Marshall et al. (1984) summarized the diversity of Pleistocene mammals in Peru. Xenarthran sites here are described from North to South and separated into three broad regions, coastal, Andean, and Amazonian following Marshall et al., 1984. Only those specimens for which the locality is known are listed.

\section{1. Coastal Region}

Paleontological sites from of the Peruvian coast are more abundant in the north than in the south (Fig. 1). Today the Peruvian coast is a desert, and except for, occasional oasis, with no vegetation. In part for this reason, paleontological sites are relatively abundant and often cover a large area. At the Cupisnique desert or those Pleistocene sites located on top of the Pisco formation, paleontological areas are often vast and may include several localities.

\section{1. 1. Miramar (Corrales San Pedro de los Incas), Tumbes}

Pleistocene - Eremotherium laurillardi (Fig. 5E-F).

Material: long bone diaphysis (MUSM 93), atlas fragment (MUSM 94), body of thoracic vertebra (MUSM 95), caudal vertebra (MUSM 96), long bone fragment (MUSM 97), vertebra fragment (MUSM 98), thoracic vertebra dorsal fragment(MUSM 99), proximal epiphysis of right ulna (MUSM 100), axis (MUSM 101), thoracic vertebra fragment (MUSM 102), left Mc V without distal epiphysis (MUSM 103), partial body of thoracic vertebra (MUSM 104), left Mc IV without distal epiphysis (MUSM 105), spinous process of dorsal vertebra (MUSM 106), bone fragment (MUSM 107), two 
skull fragments (MUSM 108), fragment of left dental with the four teeth (MUSM 109), distal epiphysis of left humerus (MUSM 110), skull fragment (MUSM 111), rib fragment (MUSM 112), right humerus diaphysis (MUSM 113), calcaneum fragment of a juvenile specimen (MUSM 114), two fragments of temporal region (MUSM 115), teeth fragments (MUSM 116), fragment of right radius diaphysis (MUSM 117), right ulna fragment (MUSM 118), occipital condyle (MUSM 119), fragment of long bone diaphysis (MUSM 120), right calcaneum without tuber calcanei (MUSM 21), right calcaneum (MUSM 122), medial half of proximal epiphysis of right tibia (MUSM 123), maxilla fragment (MUSM 124), acromion (MUSM 125), spinous process fragment (MUSM 126), Mt V diaphysis (MUSM 127), glenoid fossa of scapula (MUSM 128), spinous process fragment (MUSM 129), glenoid fossa and coracoid process of scapula (MUSM 130), olecranon of left ulna (MUSM 131), fragment (MUSM 132), and scapula fragment (MUSM 133).

The material was collected by R. Salas in high-energy alluvial Pleistocene deposits. It belongs to at least two adults of different size. Additional Eremotherium cf. laurillardi material collected in La Cruz (Tumbes) is deposited in Club Sunset, La Cruz.

\section{1. 2. La Brea-Talara, Piura}

Pleistocene - Lujanian $\left({ }^{14} \mathrm{C}\right.$ dating between $13616600 \mathrm{ybp}$ and 14,418 \pm 535 ybp, Bryan, 1973: 244) - Megatherium elenense (Fig. 7A-B, D, F, I-K), Glossotherium robustum, Scelidodon chiliensis, and Holmesina cf. paulacoutoi.

Material

Megatherium elenense: right scapula (glenoid cavity and a portion of the body, ROM 2140), body of a thoracic vertebra (juvenile specimen, ROM 2144), right Mt III (ROM 2682), right lunar (ROM 2683), sternebra (ROM 2685), left cuboid (ROM 2686), right magnum (ROM 2687), left calcaneum (ROM 2697), left astragalus (ROM 2698), right dental (fragment, ROM 3756), right lunar (partial, ROM 3778), left Mc II (ROM 3779), right navicular (ROM 3783), right Mt III (ROM 3784), diaphysis of right radius (juvenile, ROM 5391), jugal (juvenile, ROM 10401), right zygomatic arch (fragment, ROM 10402), occipital condyle (ROM 10403), right unciform (ROM 10404), fragments of thoracic vertebrae (ROM 10405-10408), sacral vertebra (fragment, ROM 10409), caudal vertebra (ROM 10410), right acetabulum (fragment, ROM 10412), fragment of acetabulum (ROM 10413), diaphysis of left tibia (juvenile, ROM 10414), diaphysis of left humerus (juvenile, ROM 10415), lunula (ROM 10417-10420), right mesocuneiformentocuneiform-complex (ROM 10422), left MEC (ROM 10423), right fibula (distal epiphysis, ROM 12690), diaphysis of right tibia (ROM 28575), left Mc III (ROM 35033), left Mc III (distal epiphysis, ROM 35872), palmar sesamoid (ROM 35873), proximal epiphysis of a radius (juvenile, ROM 35874), caudal vertebrae (ROM 35875-35878), sternal rib (ROM 35879), rib fragments (ROM 35882-35885, 35862-35896), right clavicle (fragment, ROM 35886), left ectocuneiform (ROM 35907), and several fragments of teeth.

Holmesina cf. paulacoutoi: dorsal plates (MUSM 155, 163, and 164).

No information about the remaining Xenarthra material. La Brea-Talara is one of the best known Pleistocene mammal sites of South America (Churcher 1959; 1962; 


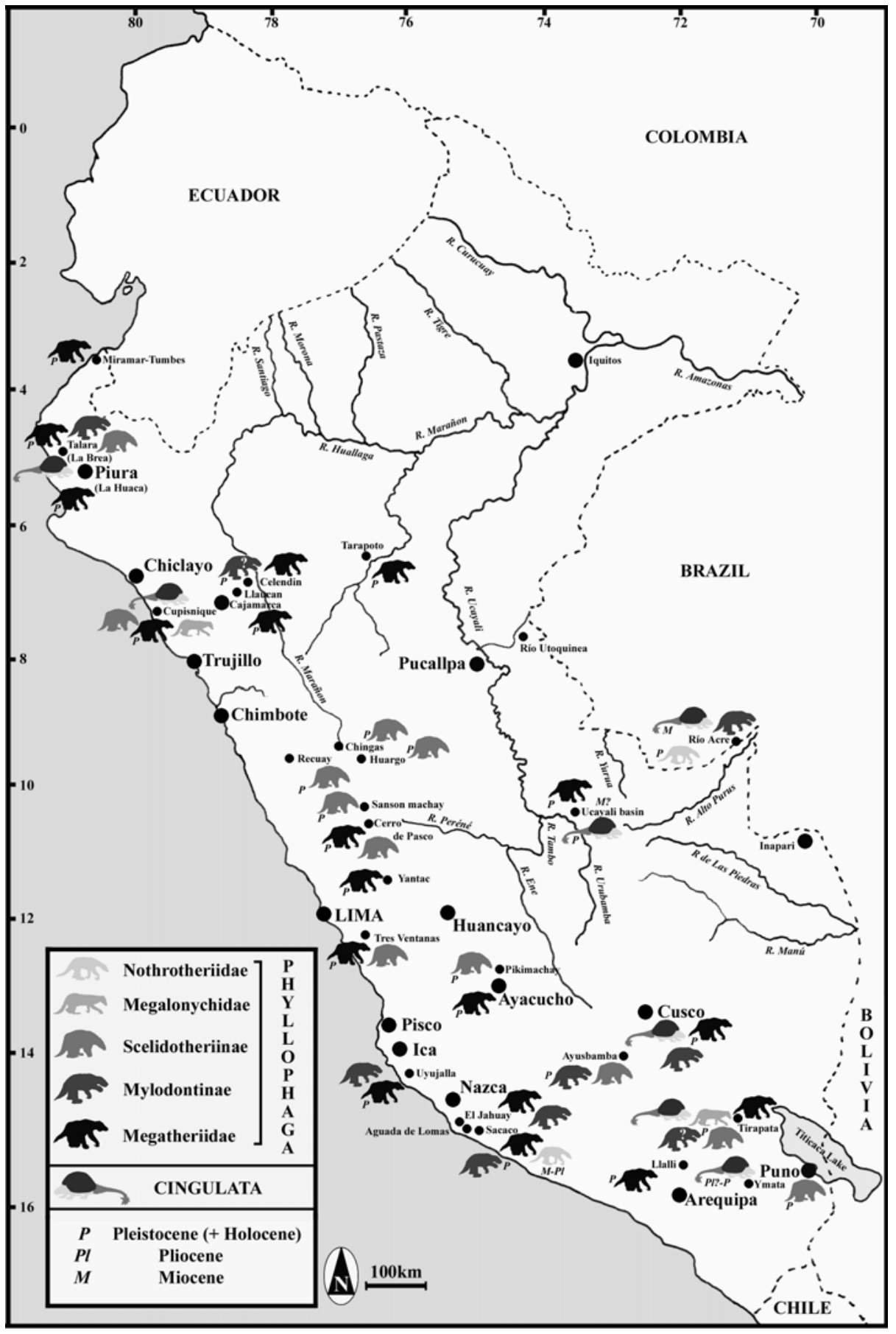

Fig. 1- Map showing Peruvian localities where Xenarthra were found. 
1965; Lemon \& Churcher, 1961; Churcher \& Zyll de Jong, 1965; Hoffstetter, 1970: 979; Marshall et al., 1984: 52-54). The name La Brea-Talara is commonly used to avoid confusion with the North American site Rancho La Brea in California (McDonald, 1987: 7). The vertebrate fauna was discovered $14 \mathrm{~km}$ south-east of Talara city (Marshall et al., 1984: 52). Lemon \& Churcher (1961) gave a faunal list of mammals that included Glossotherium sp., Scelidotherium sp., Eremotherium sp., and the armored Xenarthra Chlamytherium. According to McDonald (1987 for Scelidotheriinae), Esteban (1996 for Mylodontinae), and De Iuliis (1996 for Megatheriinae), the sloths present in Talara are Glossotherium robustum, Scelidodon chiliensis, and Megatherium elenense. Chlamytherium and Pampatherium are synonym of Holmesina (see Edmund, 1987) and the skeletal elements are extremely similar to the large Holmesina paulacoutoi from Brazil. The fauna from Talara (Lemon \& Churcher, 1961) is comparable to the Lujanian mammal fauna described by Hoffstetter (1952) from La Carolina, Ecuador.

The fauna associated with the Xenarthra includes ?Marmosa sp., ?Neochoerus sp., ?Phyllotis sp., ?Sigmodon sp., Canis sp., Pseudalopex (= Dusicyon) sp., Panthera (=Leo) sp., Smilodon sp., Conepatus sp., Stegomastodon (=Haplomastodon) sp., Equus (Amerhippus) sp., ?Tapirus sp., Palaeolama (Astylolama) sp., Odocoileus sp., and Mazama sp. (see Marshall et al., 1984: 54).

\section{1. 3. La Huaca, Piura}

Pleistocene - Lower Lujanian $\left({ }^{230} \mathrm{TH} /{ }^{234} \mathrm{U}\right.$ dating is $304000 \pm 54000 \mathrm{ybp}$, Falguères et al., 1994) - Eremotherium laurillardi and Glossotherium sp..

\section{Material}

Eremotherium laurillardi: proximal tibia (MLH 11), vertebrae fragments (MLH 14-16), rib fragment (MLH 17), associated dentary, occipital region, scapula, and rib fragments (MLH 20), femur condyle (MLH 21), proximal ulna (MLH 22), caudal vertebra (MLH 23), partial pelvis (MLH 24), partial humerus (MLH 32), partial left astragalus (MLH 33), and a vertebra of a juvenile specimen (MLH 36). Martínez \& Jacay (2000) report a dentary and a single tooth (without reference number).

Glossotherium sp.: right astragalus (without reference number, a cast kept at MUSM).

Martínez \& Jacay (2000) reported the presence of a Megatheriinae indet. near La Huaca, associated with other Pleistocene mammal remains. The fauna found at the same site and stored in MLH includes Stegomastodon (= Haplomastodon) waringi, Macrauchenia sp., Equidae, Cervidae, and Hydrochoeridae. The elements were collected in surface (Martínez \& Jacay, 2000). The specimen size, astragalus morphology, and degree of hypsodonty of the dentary, correspond to the large tropical Megathere, Eremotherium laurillardi, commonly found along the northern Peruvian coast.

\section{1. 4. Cupisnique Desert (including Pampa de los Fósiles and Piedra Escrita sites), La Libertad}

Pleistocene - Lujanian $\left({ }^{230} \mathrm{TH} /{ }^{234} \mathrm{U}\right.$ dating between $25 \quad 00 \notin 1 \quad 000$ and $1500 \%$ 500 ybp, Falguères et al., 1994 and contra ${ }^{14} \mathrm{C} 891 \notin 200$ ybp [on Scelidodon chiliensis 
MNHN CPN 16] suggested by Marshall et al., 1984) - Eremotherium laurillardi (Figs. 5B-C, D, G, J-K, 6A, C, D, F, G, I-K), Scelidodon chiliensis (Fig. 4A, E-G), Megalonychidae gen. nov. (Pujos, 2000; 2002b; Pujos et al., 2004; in preparation), and Holmesina cf. paulacoutoi.

\section{Material}

Eremotherium laurillardi: proximal two thirds of Mt V (HDD PV22-44-U12); two large specimens represented by cranial and mandibular portions (HDD PV22-40); several postcranial elements of a single specimen without skull but with atlas, axis, several thoracic vertebrae, portions of both radii, right clavicle, right femur (proximal epiphysis), right tibia-fibula (poorly preserved), and both astragali (HDD PV22-44U9).

Scelidodon chiliensis: a sub-complete specimen (MNHN CPN 16) described by Pujos (2000); a poorly preserved right foot which consists of tibia (distal epiphysis), of calcaneum fragment, navicular fragment, of astragalus fragment, fragments of metatarsals and phalanx, two sesamoids (cyamo-fabella and ossified meniscus from the knee joint as in Megatheriinae and the Mio-Pliocene nothrothere Thalassocnus, Salas et al., 2002). Moreover several osteoderms were discovered associated with the skeleton (HDD PV22-44-U6).

Megalonychidae gen. nov.: a single partial specimen with skull, dentary, and post-cranial elements (MNHN CPN 9-1) under study (Pujos, 2002b; Pujos et al., 2004; in preparation).

Holmesina cf. paulacoutoi: three phalanges, one carpal (scaphoid?), a fragment of maxilla, and several undetermined fragments (all under the reference number HDD PV22-108-U3); fragments of skull and dental (HDD PV-22-109), and several plates coming from various localities of Cupisnique desert.

The first discoveries in the Cupisnique Desert were made by UbberlohdeDoering (1939). The Cupisnique Desert is located from 50 to $100 \mathrm{~km}$ north of Trujillo city (600 km north of Lima).

The material mentioned in this work has been collected over twenty years by the Paleontological mission of the IPGQ. A part of MNHN CPN 16 is yielded at MNHN as well as specimen MNHN CPN 9-1 (Pujos et al. 2004, and in preparation), collected by a Hoffstetter-Chauchat mission in 1975 at Piedra Escrita site (Pujos, 2002b; Pujos et al., 2004).

The Pleistocene mammal fauna includes Xenarthra and Stegomastodon (= Haplomastodon) sp., Neochoerus sp., Palaeolama sp., Equus (Amerhippus) santaeelenae, Odocoileus sp., and Pseudalopex (= Dusicyon) sp. (Marshall et al., 1984; Collina-Girard et al., 1992; Pujos, 2000; 2002b).

This region is especially well known for its archaeological sites (Chauchat, 1998) but none have been shown to be related to any of the Pleistocene paleontological sites. Pleistocene levels of the Cupisnique Desert are formed by heterometric breccia with large elements (channel deposits where the fossiliferous levels are located), aeolian sands and windworn, and littoral limestones (Pujos, 2002b).

All specimens come from Pampa de los Fósiles except MNHN CPN 9-1 which is from Piedra Escrita. 
2. 1. 5. Uyujalla (= Samaca) - Ocucaje, Ica

Pleistocene - Megatherium cf. urbinai and Mylodontidae indet.

Material

Megatherium cf. urbinai, complete skeleton of a sub-adult individual collected (Fig. 2, pictures of the specimen before its loss).

Mylodontidaeindet.: manubrium sterni, right unciform, phalanges, and osteoderms (MUSM 452).

Unusual specimen of the Megatheriid Megatherium cf. urbinai found in aeolian deposits, preserved soft tissue (Fig. 2). Unfortunately, the specimen has disappeared before to be collected.

Previous discoveries on the site reported by Casa-Vilca (1958) and others stored in MUSM include Stegomastodon (= Haplomastodon) waringi and Equus (Amerhippus) santaeelenae. Recent field work has permitted the discovery by M. Urbina and one of us (F. Pujos) of new specimens of Megatherium cf. urbinai and Mylodontinae sp. associated with Stegomastodon (= Haplomastodon) sp., Equus (Amerhippus) sp., Cervidae, and Canidae.

\section{1. 6. Quebrada El Jahuay, Arequipa}

Pleistocene - Megatheriidae indet. and Mylodontidae indet.

Material:

Megatherium (Pseudomegatherium): mandibular portion of an adult (MUSM 450) and right maxilla of a juvenile (MUSM 409).

Glossotherium sp.: left femur (MUSM 451).

These fluvial deposits were discovered by M. Urbina and T. DeVries in 2002. They run along the Santa Lucia River near the El Jahuay area. Faunistic association, that includes Phyllophaga, Stegomastodon (= Haplomastodon) waringi, and Equus (Amerhippus) santaeelenae, indicates Lujanian SALMA.

\section{1. 7. Sacaco - Aguada de Lomas, Arequipa}

Pleistocene-Megatherium urbinai (Pujos \& Salas, 2002; 2004) and Glossotherium sp..

Material

Megatherium urbinai: partial skeleton (without skull), teeth and axial skeleton (except the tail) (MUSM 15, Fig. 8, Pujos \& Salas, 2002; 2004).

Glossotherium sp.: dentary with poorly preserved teeth of an immature specimen (MNHN-PRU9).

The Quaternary deposits were identified as "estructuras de flujo formadas por materiales tobáceos y cenizas con limos y arcillas gris-blanquecinas"(Caldas Vidal, 1978).

Hoffstetter (1968) reported that: "Equidé (Equus)", had originated from "une couche blanche récente (peut-être Holocène), peu cohérente, qui recouvre par place les sédiments marins". A geological and paleoenviromental analysis of this locality is in progress by Pujos \& Pichon. 
Xenarthrans are associated with Equus (Amerhippus) santaeelenae, Lama guanicoe, Stegomastodon (= Haplomastodon) sp., Calomys sp., and Conepatus sp. (Salas \& Stucchi, 2002).

\section{2. Andean Region}

Paleontological sites are abundant in the Peruvian Andes (Fig. 1). Practically all the paleontological remains were discovered in caves, often by speleological expeditions.

2. 2. 1.Celendín ( 2 $500 \mathrm{~m}$ including Llaucán) - Celendín (2 $650 \mathrm{~m}$ ) Cajamarca

Pleistocene (Lujanian, dating in progress by IPH) - Megatherium sp. nov. (Pujos, 2001; 2002b; in progress), Megatheriinae indet., and perhaps Mylodontidae indet. (see Marshall et al., 1984: 55).

\section{Material}

Megatherium sp. nov.: partial skeleton with skull (MUSM 157 from Santa Rosa Cave, see Pujos, 2001; 2002a).

Megatherium sp.: partial and poorly preserved specimen (MUSM 158, from Huayobamba, $30 \mathrm{~km}$ to Celendín).

Megatheriinae indet.: several teeth fragments (UNI 667 from "Provincia de Cajamarca, Terciario"), glenoid cavity of a scapula (UNI H1 from "Los Paucos, Celendín").

Megatherium sp.: astragalus and some other postcranial elements from Llaucán, Bambamarca (Maguiña, 1988). confirmed.

The presence of Mylodontidae is stated by Marshall et al. (1984) but has not been

Several localities with Stegomastodon (= Haplomastodon) and Megatheriidae are present in the karstic mountains of the Cajamarca area approximately at an altitude of $2500 \mathrm{~m}$ (Hoffstetter, 1970: 977; Marshallet al., 1984: 54). Pleistocene faunas in caves are common in karstic areas and have been discovered during French speleological expeditions (altitude between 3350 and $3550 \mathrm{~m}, 20 \mathrm{~km}$ South of Celendín; see Sanmartino et al., 1981 in Hoffstetter, 1986). Panthera onca (= Felis (Jaguarius) onca andinus) and Onohippidion cf. peruanum in particular have been found there. Megatherium sp. material from Llaucán was deposited in the public school of the city (Maguiña, 1988). A visit by one of us (R. Salas) in 1999, revealed that the material is now lost.

Megatherium sp. nov (MUSM 157) comes from Santa Rosa Cave near the city of Celendín (Pujos, 2001; 2002b; in progress), which is part of a karst system. This taxon, collected by one of us (F. Pujos), was found and associated with Cervidae, and Muridae. Preserved floral remains indicate the presence of fern spores from the surrounding areas of the cavity (Pujos, 2002a). MUSM 158 is a large Megatherium specimen. The metacarpal-carpal-complex (MCC) of the specimen is typically Megatherium (fusion of the trapezium-first digit) and similar in shape to the MCC of M. (P.) tarijense. 
2. 2. 2. Recuay (4 350 m), Ancash

Pleistocene - Scelidotheriinae indet.

Material

Partial skeleton found by Ing. Orlando Felix and referred by Rangel \& Romero (1985).

This skeleton is not registered in any Peruvian Institution. A partial postcranial Scelidotheriinae without locality information is deposited in UNMSM and could correspond to this specimen.

\section{2. 3. Chingas (4 $350 \mathrm{~m})$, Ancash}

Pleistocene (probably Lujanian or early Holocene, dating in progress by IPH) Scelidodon chiliensis (Fig. 3).

Material

Complete specimen without reference number conserved at the Chingas council. A cast of the specimen is preserved at MUSM and a cast of the skull and dentary at the MNHN.

This specimen was discovered in the sediments of Yanacocha lagoon in 1991 by the Chingas community. It was mounted by R. Salas at MUSM before returning to the INC. The exceptional preservation of the specimen permits the possibility that original paleo-DNA may be preserved (in progress MNHN). The Scelidodon sp. specimen is associated with remains of an Equidae indet.

\section{2. 4. Huargo (4 $050 \mathrm{~m})$, Huánuco}

Pleistocene - Lujanian (dating of Huargo Cave bed 8: ${ }^{14} \mathrm{C} 13$ 460世 $700 \mathrm{ybp}$, Cardich, 1973: 30) - Scelidotheriinae indet. (Marshall et al., 1984: 55; Hoffstetter, 1986: 228).

\section{Material}

Left Mc IV, vertebra, right and left M1-4, and right m4 (without catalog number and maybe conserved at the INC, see Pascual \& Odreman Rivas, 1973: 31-32).

The Lujanian fauna contains Scelidotherium s.l. (most probably Scelidodon) associated with Parahipparion sp., Lama sp., and Puma sp. (Hoffstetter, 1986: 230). The cave is located south of the city of La Unión, (Pascual \& Odreman Rivas, 1973)

\section{2. 5. Sansón-Machay (4 400 m), Pasco}

Pleistocene - Scelidotheriinae indet. (Scelidotherium according to Gervais, 1855: 48-49; Hoffstetter, 1970: 978; 1986: 228).

Material

Dentary fragment (with three teeth), two dorsal vertebrae, a partial sternum, an incomplete scapula, and two fibulae (without reference number and location of the material, see Gervais, 1855: 49-50). 
The fauna was originally discovered by the Castelnau expedition at the end of the nineteenth century. Sansón-Machay is located near to Cerro de Pasco City (Hoffstetter, 1970: 976). The fauna was studied and described by Gervais (1855). According to Marshall et al. (1984: 55) the cave is located $2 \mathrm{~km}$ east of Guayllarisquizga.

\section{2. 6. Cerro de Pasco (4 $300 \mathrm{~m}$ ), Pasco}

Pleistocene - Megatherium elenense (Fig. 7C, E, G-H, L-N), Scelidodon cf. chiliensis (Fig. 4C-D).

Material

Megatherium elenense: a single specimen, MUSM 134, consisting of 14 vertebrae, rib fragments, pelvis, proximal epiphysis of left femur, left astragalus (without odontoid process), left Mc II-IV, anterior phalanges (left (1-2) III, right 1 II, left 3 III, right partial $3 \mathrm{IV}$, right $\mathrm{Mt} \mathrm{V}$, posterior phalanx (right $3 \mathrm{III}$ ).

Scelidodon cf. chiliensis: a radius (MUSM 122 and associated with MUSM 134).

MUSM 134 specimen of Megatherium is similar to the elements of $M$. (P.) elenense from Talara. It is also similar to $M$. (P.) urbinai (MUSM 15 specimen from Sacaco, Pujos \& Salas, 2002; 2004) and M. (P.) tarijense from Tarija (FMNH P14216). Hoffstetter (1986: 227) considered that these remains belonged to a new genus of megathere. One scelidothere humerus from the same locality is associated with MUSM 134. This element shows the same characteristics as Scelidodon chiliensis MNHN CPN16, the specimen from Pampa de los Fósiles (Cupisnique Desert).

\section{2. 7. Yantac (4 $500 \mathrm{~m}$, including Tarma), Junín}

Pleistocene - Megatherium (Peusomegatherium) tarijense (Figs. 9-10) and Megatheriinae indet..

\section{Material}

Megatherium (P.) tarijense: one partial specimen armed (UNI 1) consisting of the skull, dentary, right scapula, both humeri, both femora, pelvis, and several vertebrae (7 cervicals, 16 thoracics, 3 lumbars, and 3 caudals).

Megatheriinae indet.: distal epiphysis of left femur from Tarma.

The specimen of M. (P.) tarijense was collected by Eugenio Alecchi in lacustrine deposits near to Yantac city. The discovery was reported by Lisson (1912). The specimen is exposed and conserved in the Geological Department of the UNI (Figs. 910). UNI 1 was considered by Hoffstetter (1986: 227) as an unnamed new genus of megathere.

This well preserved specimen is extremely similar to the complete specimen of M. (P.) tarijense (FMNH P14216) from Tarija (Bolivia). The small differences between both specimens are considered as intra-specific variations. It is the most complete megathere skull from Peru. It is typical of the Andean Megatherium lineage recognized by Pujos et al. (2002). It is a small sized Megathere that is distinguished by "X-shaped" premaxillae, posteriorly prominent occipital condyles, and straight lateral margin of the 
femur which is poorly twisted. The distal femur from Tarma is deposited at the Museo de la Universidad Nacional de San Martín without catalog number. Its preservation does not permit a determination under the subfamily level.

\section{2. 8. Tres Ventanas Cave (4 000 m), Lima}

Pleistocene - Lujanian $\left({ }^{14} \mathrm{C}\right.$ dating: older than $40000 \mathrm{ybp}$, Engel, 1970) Megatherium (P.) urbinai, Scelidodon cf. chiliensis (as suggested by Hoffstetter, 1970: 977; Fig. 4B).

\section{Material}

M. (P.) urbinai: one hand, one foot, ribs, and vertebrae (UNA V2642), see Pujos \& Salas (2004).

Scelidodon cf. chiliensis: immature right humerus (same reference number than M. (P.) urbinai).

Both specimens were collected by F. Engel in Cave Number 2 of Tres Ventanas Cave (70 km east-south-east of Lima, Engel, 1970). The fossil bed is overlayed by a bed that preserves evidence of human activity and dated to $6080 \mathrm{ybp}$ (Engel 1970). The Megatherium specimen was identified as Megatherium sp. by Hoffstetter $(1970 ; 1986)$ and is now referred to Megatherium (P.) urbinai by Pujos \& Salas $(2002 ; 2004)$.

2. 2. 9. Ayacucho Valley (including Pikimachay cave, $2800 \mathrm{~m}$ ), Ayacucho

Pleistocene-Lujanian $\left({ }^{14} \mathrm{C}\right.$ dating of Pikimachay cave between $14 \quad 15 \notin 180$ and $19620+3000 \mathrm{ybp}$, McNeishet al., 1970) - M. (M.) americanum or M. (P.) tarijense (McNeish et al., 1975, identification by B. Patterson; Hoffstetter, 1986: 227), Scelidotherium tarijense (i.e. Scelidodon sp., in Pikimachay cave [= Flea Cave], Marshall et al., 1984: 55; Hoffstetter, 1986: 228-229).

Material not listed by the authors.

Following McNeish (1971) and McNeish et al. (1970; 1975), Marshall et al. (1984) note the presence of these two sloths along with Equus sp., Cervidae sp., Lama sp., Felidae, Pseudalopex (= Dusicyon) sp., Conepatus sp., Lagidium sp., and Phyllotis sp.

\section{2. 10. Ayusbamba (3 $800 \mathrm{~m}$ ), Cusco}

Pleistocene - Scelidotheriinae indet. (Hoffstetter, 1970: 978; 1986: 228), Mylodontinae (Mylodon for Eaton, 1914; Glossotherium?, Hoffstetter, 1986: 229).

\section{Material}

Mylodontinae: proximal epiphysis of a humerus (Eaton, 1914: 148 and figs. 5-6).

Scelidotheriinae: no specific information given by Hoffstetter (1970; 1986).

Phyllophaga indet.: fragmentary teeth (MUSM 74-75) and the diaphysis of a humerus (MUSM 73).

The open-air site of Ayusbamba is located south of Cusco (Gregory, 1914; Ramírez Pareja, 1958). The proximal epiphysis of the mylodontine humerus does not permit a determination beyond the subfamily level. Hoffstetter (1986) considered that 
all the mylodontine remains from this area probably belong to Glossotherium sp. Material recently collected and stored in MUSM confirms the previous report of this Xenarthra, Cuvieronius hyodon, Lama sp., Cervidae and Equidae (Eaton, 1914).

2. 2. 11. Cusco Valley (3 350 m, including San Sebastián - Corimachachuay, Huanaro, and Wimpillay), Cusco

Pleistocene - M. (P.) tarijense or M. (M.) americanum (Hoffstetter, 1970: 977978; 1986: 227) and Glyptodon cf. clavipes (Kalafatovich, 1955; Hoffstetter, 1970: 978 , 1986: 229) from Cusco; Mylodontinae (Glossotherium?, Hoffstetter, 1986: 229) from Huanaro (south of Cusco).

\section{Material}

M. (P.) tarijense or M. (M.) americanum: a twisted femur (see Hoffstetter, 1986: $227)$ and deposited at the Cusco INC with no reference number.

Mylodontidae: no specific information given by Hoffstetter (1986: 229).

Glyptodon cf. clavipes: "carapace and fragments of several bones" (Kalafatovich, 1955: 154-155) and a complete specimen (R. Salas, pers. obs., 2001).

If the megathere femur mentioned by Hoffstetter is actually twisted, the specimen mentioned may belong to $M$. (M.) americanum or $M$. (M.) altiplanicum but not to $M$. $(P$.) tarijense in which the femur is poorly twisted.

Kalafatovich (1955) described Glyptodon remains from San Sebastian (in Corimachachuay), near Cusco. The elements come from the sediments of ancient Lake Makril and are held at UNSA (R. Salas pers. obs, 2001).

A complete skeleton of Glyptodon cf. clavipes was discovered at Cerro Wimpillay in 1998. The specimen is mounted and exposed in the Museo Histórico Regional Casa Garcilaso, Cusco.

\section{2. 12. Llali (3 $900 \mathrm{~m}$ ), Arequipa}

Pleistocene - Megatheriinae indet. (Hoffstetter, 1970: 978; 1986: 227).

Material

A femur of a small Megatheriinae kept at the University of Arequipa (Hoffstetter, 1986: 227).

Hoffstetter (1986) does not provide more information about this femur.

2. 2. 13. Tirapata area including Casa del Diablo Cave (3 $819 \mathrm{~m})$ and Azángaro Cave (3 859 m), Puno

Pleistocene-Scelidotheriinae (Scelidodon sp.), Mylodontinae (Glossotherium?, Hoffstetter, 1986: 229), Megatherium sp., and Megalonychidae gen. nov. (Pujos, 2002b; Pujos et al., 2004) from Casa del Diablo Cave; Megatherium sp. (Marshall et al., 1984: 55; Hoffstetter, 1986: 227) and Glyptodontidae indet. (Hoffstetter, 1970: 978) from Azángaro Cave. 


\section{Material from Casa del Diablo Cave}

Scelidotheriinae: dentary of an immature specimen associated with other fragmentary elements (Nordenskiöld, 1908: 20)

Mylodontinae: mentioned without any details by Hoffstetter (1986: 229) but not by Nordenskiöld (1905; 1908).

Megatherium sp.: one calcaneum(NRMM4451) and one astragalus (NRMM4290) (material under study by De Iuliis et al.).

Megalonychidae gen. nov.: a complete left humerus (NMR-PZ M4286) figured by Nordenskiöld (1908: fig. 2) and a right dentary without teeth (NRM-PZ M4287).

Material from Azángaro: lower jaw of a small megathere unnamed genus (Hoffstetter, 1986: 227) and an unidentified Glyptodont (Hoffstetter, 1970: 978).

Casa del Diablo Cave is located near Tirapata (Hoffstetter, 1970: 976). The presence of Mylodontinae in Casa del Diablo Cave is uncertain because it is not mentioned by Nordenskiöld who discovered the cave and the paleontological remains. The megalonychid bones elements are under study (Pujos, 2002b; Pujos et al., 2004) and are similar to the megalonychid remains from Piedra Escrita (Cupisnique Desert, Peruvian Coast). The astragalus-calcaneum complex from Casa del Diablo Cave is similar to $M$. (M.) americanum but extremely small (out of intra-specific size variation of this Megatherium species).

\section{2. 14. Ymata $(\sim 3850 \mathrm{~m})$, Puno}

Pleistocene (Pliocene?) - Glyptodontidae cf. Panochthus sp. (see Hoffstetter, 1970: 978).

Hoffstetter (1970: 978) does not give more information about the armored Xenarthra from Ymata. For Hoffstetter (1986: 226), the age could be Pliocene or Pleistocene. Remains were collected by Parodi during the fifties in the hacienda Ymata.

\section{3. Amazonian Region}

Paleontological sites are extremely rare in the Amazonian forest region because of the presence of acid environment (which destroy the paleontological remains) and the presence of luxuriant vegetation (Fig. 1) which limits the number of exposed areas.

\section{3. 1. Tarapoto, San Martín}

Pleistocene - Eremotherium cf. laurillardi.

Material of Eremotherium cf. laurillardi

Sub-complete right astragalus (MUSM 22, Fig. 11A, D, G).

The astragalus has been collected by Tarapoto residents in Pleistocene deposits exposed near the confluence of Mayo and Huallaga Rivers. A gomphothere, possibly Stegomastodon (= Haplomastodon), was reported from this site (Raimondi, 1898). Additionally, Willard (1966) mentions the presence of a Toxodontidae indet. 
2. 3. 2. Río Acre - "Iñapari Formation", Madre de Dios

Holocene (maximum radio isotopic date: $11000 \mathrm{ybp}$ ) Nothropus priscus.

Material

Partial skeleton that lacks the left hind limb and both hind feet (LACM 117533, Frailey, 1986: 34).

Only the skull and dentary have been described by Frailey (1986). The mammal fauna comes from the "Acre Conglomerate Member" of the Holocene Iñapari Formation which is composed of four members named by Frailey (1986: 5).

Nothropus priscus comes from the Member A of this formation (Frailey, 1986: 6).

\section{3. 3. Ucayali basin (Río Inuya and Río Ucayali), Ucayali}

Pleistocene - Eremotherium sp., Glyptodon sp..

Material

Eremotherium sp. (from Río Ucayali), no details were given by Buffetaut \& Hoffstetter (1977: 1663).

Glyptodon sp. (from Río Inuya): dentary and plates (Willard, 1966: 238-239)

Fossiliferous Pleistocene levels are located above the Miocene Ipururo Formation.

Eremotherium sp. remains are associated with Stegomastodon (= Haplomastodon) sp. and Toxodon sp..

\section{DISCUSSION}

The distribution of Peruvian Xenarthra is quite heterogeneous in time and space (Fig. 1). Pre-Pleistocene Xenarthra are present in the Mio-Pliocene Pisco Formation as represented by the aquatic or sub-aquatic lineage of Thalassocnus (McDonald \& Muizon, 2002) and in two Amazonian sites (Río Ucayali and Río Acre) (Table 1). The Phyllophaga remains from the Middle Miocene of Río Ucayali are fragmentary (Buffetaut \& Hoffstetter, 1977) but represent the oldest documented Peruvian Xenarthra. No other remains of Acremylodon campbelli from Río Acre (Late Miocene) has been mentioned since Frailey's publication (1986). A possible Pliocene Cingulata (Glyptodontidae cf. Panochthus sp.) could be present in the south of the Andes (Ymata) but this data is not reliable (Hoffstetter, 1986).

Pleistocene Peruvian Xenarthra are abundant (Figs. 2-11, Table 2). They are present in some coastal localities, in nearly all of the Andes, and in three Amazonian sites.

The large Pampathere Holmesina cf. paulacoutoi (Cingulata) has been reported from Peru by Edmund (1987). Several plates have been discovered in the Talara Tarbeds and from the Cupisnique Desert (Peruvian coast). Holmesina is absent in the Andes. Glyptodon clavipes is present in the Cusco and Puno areas. According to Hoffstetter (1986: 229), no fossil Pleistocene Dasypodidae are known from Peru. 
Phyllophaga are common in Peru (Fig. 1). Fossil sloths were apparently not limited by geographic barriers (such as the Andes). They are rare in the Amazonian forest region essentially because of the absence of paleontological sites, but are common on the coast, and extremely abundant in the Andes.

Nothropus priscus (Río Acre, Frailey, 1986) is the only Pleistocene-Holocene Nothrotheriidae present in Peru. A detailed anatomical description of the specimen is necessary to appraise its relationships with Nothrotherium and Nothrotheriops (from the Pleistocene of Brazil and North America respectively).

Mylodontidae are represented by the mylodontine Glossotherium sp. on the coast (several specimens from Talara and one dentary from Sacaco) and more rarely in the Andes (one partial humerus from Ayusbamba and maybe also in Cusco, Casa del Diablo, and Cajamarca). The Mylodontidae scelidothere Scelidodon chiliensis (Figs. 34) is more abundant than Glossotherium robustum. Scelidotherium leptocephalum has been found in Argentina (Hoffstetter, 1986) and Uruguay (Mones, 1986). The subcomplete scelidothere specimens from Peru, e.g. Chingas (Fig. 3), MNHNCPN 16 from Pampa de los Fósiles (Pujos, 2000; Fig. 4E, F-G), and material from Talara, belong to Scelidodon chiliensis. Moreover, the intraspecific variation in S. chiliensis specimens is minor.

Members of the Megatheriinae are the most abundant Phyllophaga in Peru (Figs. 2, 5-11). They are present in nearly all the Peruvian Pleistocene sites. Both Pleistocene genera, Megatherium and Eremotherium, are abundant in Peru.

The tropical genus Eremotherium (species E. laurillardi) is reported only from the northern part of the Peruvian coast (Miramar, Tumbes, Cupisnique, La Huaca, and Piura) to latitude $8^{\circ}$ South (Figs. 5-6). Morphological variability in Megatheriinae is extremely important according to De Iuliis (1996), Pujos \& Salas (2004) and Pujos (2001 and new species under study). On the northern coast of Peru Megatherium and Eremotherium might have been sympatric. Material from La Brea (Talara) conserved at the ROM is similar to the small megathere specimens from Santa Elena (Ecuador) described by Hoffstetter (1952) as "Eremotherium elenense" (= Megatherium (P.) elenense) (Fig. 7). The small sized temperate megathere $M$. (P.) elenense (approximately half the size of E. laurillardi) belongs to the Andean linage recognized by Pujos et al. (2002) that forms the clade $[M$. (P.) tarijense $+M$. (P.) elenense $+M$. (P.) urbinai $+M$. (P.) sp. nov. from Celendín] within the subgenus $M$. (Pseudomegatherium). A revision of $M$. (P.) elenense is necessary to establish its phylogenetic relationships within of the subgenus Megatherium (Pseudomegatherium). The Andean megathere was more of a grazer than browser contrary to what is commonly considered for the largest plain-dwelling megatheres E. laurillardi and $M$. (M.) americanum (Pujos et al., 2002). Moreover, pairs of large and small sized sloths have been recognized to have shared a common habitat, like the large $M$. (M.) americanum and the small M. (P.) tarijense, present in Tarija (Bolivia), and the large E. laurillardi and the small M. (P.) elenense in Santa Elena (Ecuador). E. laurillardi and $M$. (P.) elenense may therefore have cohabited the same area until the end of Pleistocene in northern Peru. A new small sized Megatherium species was discovered in both the 
coastal region and in the Andes of Peru (Megatherium (P.) urbinai, Fig. 8; Pujos \& Salas, 2002; 2004).

M. (P.) tarijense is known only by the partial specimen UNI 1 from Yantac (Andean Pleistocene site, Figs. 9-10). Hoffstetter (1986: 227-228) suggested the existence in the Peruvian Andes of a megathere, a "smaller, unnamed genus, with at least two species of different sizes...". The only small sized megatheres known from in the Andes are M. (P.) tarijense (Yantac) and M. (P.) urbinai (Tres Ventanas, Pujos \& Salas, 2004). In Peru, $M$. (P.) elenense is only reported on the northern coast (Talara) and in the central Andes (Cerro de Pasco). Moreover, a large and peculiar megathere has been discovered in the northern part of the Peruvian Andes. Pujos (2001) first considered this partial specimen as a megathere clearly distinct from Megatherium and Eremotherium. However, the discovery of additional material required Pujos to include this taxon in Megatherium genus (Megatherium (Pseudomegatherium) sp. nov., Pujos, 2002b and under study).

All these small-sized Andean Megatherium (Pseudomegatherium) species are distinct from the second Megatherium clade [M. (M.)americanum + M. (M.)altiplanicum $]$ (=Megatherium (Megatherium)), of St-André \& De Iuliis (2001). They are distinguished by the weak degree of hypsodonty in the mandible and a poorly twisted femur. These characters of the subgenus Megatherium (Pseudomegatherium) defined by Pujos (2002b) seem to correspond to the "unnamed genus" previously described by Hoffstetter (1986: 227-228). These "Peruvian Andean" species (M. (P.) elenense, M. (P.) tarijense, $M$. (P.) urbinai, and Megatherium (P.) sp. nov.) are located in the Andes and/or in the coast but not in the Amazonian forest Region. The Andean lineage range seems to include northern Chile, Bolivian altiplano, and coast of Ecuador.

A peculiar megathere astragalus has been reported from Tarapoto. The astragalus (MUSM 22) is gigantic (Fig. 11A, D, G) and quite similar to Eremotherium laurillardi based on the large distance between the discoid and ectal facets (in dorsolateral view). It is the largest megathere astragalus currently known reaching an anteroposterior length (APL) of $285 \mathrm{~mm}$. Some large astragali of E. laurillardi from Florida (APL $=238 \mathrm{~mm}$, UF 115692; APL $=224 \mathrm{~mm}$, UF 7474) show a slightly posteromedial extension of the odontoid process and a flat discoid facet (in dorsolateral view) as the specimen from Tarapoto and contrasting smaller E. laurillardi samples. In anterior view, the angle between the odontoid and discoid facets is approximately $90^{\circ}$, less than that of Megatherium and Eremotherium genera. Morphological differences in big specimens of E. laurillardi might be related to huge size. The discovery of more material is necessary to understand possible consequences of gigantism in the locomotor apparatus of Eremotherium.

Finally the most interesting Xenarthra from Peru is the Phyllophaga reported by Nordenskiöld (1908) and published by Kraglievich (1926; 1931) as "cf. Nothropus nordenskioldi". The holotype is a humerus from Casa del Diablo Cave in the Andes (Puno Department) and a sub-complete specimen referred to this taxon discovered by Hoffstetter and Chauchat in 1975 (see Marshall et al., 1984) at the Piedra Escrita Site in the Cupisnique Desert. This taxon (Pujos et al., 2004, and under study) is a new Megalonychidae which shows climbing capabilities (Argot \& Pujos, 2003), although it 
is clearly distinct from the modern tree-sloths Bradypus and Choloepus that currently inhabit the Amazonian forest. If we consider the Nothrotheriidae as a distinct family (according to Gaudin \& De Iuliis, 1999), it turns out that this later new taxon represents the only true Peruvian Megalonychidae. Hoffstetter (1986: 230-231) also indicated the presence of a "medium-sized megalonychid (ulna, vertebrae, etc.)" from Gruta Blanca, Parque Nacional Cutervo (Sanmartino et al., 1981 in Hoffstetter, 1986) but did not provide details.

\section{CONCLUSIONS}

As in other South American countries, the Xenarthra constitute a large part of the Pleistocene mammal fauna of Peru. Except for a nothrothere lineage from the Pisco Formation, a mylodont from Río Acre, and Glyptodontinae and Dasypodidae from Río Utoquinea, Peruvian fossil xenarthrans are from Pleistocene beds. The origin of Peruvian Xenarthra is poorly known because of the absence of material from sites earlier than the mid Tertiary and because faunal turnover between the Late Miocene, Pliocene, and Holocene are not well documented in the country. Based on the current available specimens the major features of the paleogeographical history of Peruvian Xenarthra are:

- most of Peruvian Xenarthra are known from sites dating to the end of the Pleistocene (Lujanian) and/or Holocene;

- Pleistocene Cingulata are poorly represented in Peru:

- Holmesina cf. paulacoutoi is present only on north and middle of the coastal region (at latitude $5-7^{\circ}$ South),

- Glyptodon clavipes is present only in the Cusco-Puno area,

- by contrast, Pleistocene Phyllophaga are abundant, although relatively poorly diversified taxonomically (except for the genus Megatherium), and are found in all three regions, the coast, Andes, and Amazonian forest. They are commonly found in Andean caves, particularly between 2500 and $4500 \mathrm{~m}$ in elevation,

- Nothropus priscus from Río Acre (Amazonian forest) is the only Pleistocene Nothrotheriidae recognized in Peru, and Brazil:

- Peruvian Mylodontidae are not abundant in contrast to those from Argentina

- a few Mylodontinae (i.e. Glossotherium robustum) were found in the Andes and Peruvian coast (Talara an d Sacaco),

- a single Scelidotheriinae (i.e. Scelidodon chiliensis) is present in Peru but is abundant in several coastal and Peruvian localities,

- Megatheriinae represent the most abundant Peruvian Xenarthra:

- Eremotherium sp. is abundant in the northern part of the Peruvian coast (i.e. E. laurillardi) and probably in some Amazonian localities (e.g. Tarapoto); this tropical genus is typically found in plains and does not seem to have been adapted to an Andean environment,

- the subgenus Megatherium (Pseudomegatherium) includes 4 species in Peru $[M .(P$.$) tarijense +M .(P$.$) elenense +M .(P$.$) urbinai +$ Megatherium $(P$.$) sp.$ 
nov. from Celendín]. It has been found in several Andean sites (e.g. CelendínMegatherium (P.) sp. nov., Yantac-M. (P.) tarijense, Tres Ventanas -M. $(P$. urbinai, Cerro de Pasco-M. $(P$.$) elenense) and two coastal sites (Talara-La$ Brea-M. (P.) elenense and Sacaco-M. (P.) urbinai) but not in the Amazonian forest region. The Andean lineage (which also includes the Chilean forms $M .(P$.$) medinae and M$. (P.) sundti) is characterized by a small size (except Megatherium (P.) sp. nov. from Celendín), a low degree of hypsodonty, prominent occipital condyles, a poorly twisted femur, and a high torsion degree of the feet,

- Megatherium (Megatherium) s.s. (i.e. [M. (M.) americanum + M. (M.) altiplanicum]) is not reported from Peru and seems to be more characteristic of the Argentinian Pampas (M. (M.) americanum) and Bolivian Altiplano (M. (M.) americanum from the Pleistocene of Tarija, M. (M.) altiplanicum from the Pliocene of Ayo Ayo),

- a new peculiar small-sized Pleistocene Megalonychid is reported from Piedra Escrita (coastal desert) and Casa del Diablo (Andean cave near Lake Titicaca). This strange sloth (Argot \& Pujos, 2003; Pujos et al., 2004 and under study) shows several characters that could suggest an arboreal mode of life (but distinct from the suspensory mode of locomotion of modern tree-sloths, Argot \& Pujos, 2003).

The last fossil Xenarthrans (fossil sloths, Pampatheriidae, Glyptodontidae) disappeared in Peru at the beginning of the Holocene. Xenarthra is the one of the most diversified mammal group of the South American Pleistocene (Patterson \& Pascual, 1972). They survived to the Great American Biotic Interchange and competition with new large North American emigrants (after the formation of the Panama isthmus) and several important glacial/interglacial periods during the Pleistocene. This raises several questions, as: Why did this group which colonized all American biotopes (from Alaska to Patagonia and from the Amazonian forest to the Andean summits) disappear? What is the new South American event at the Pleistocene/Holocene transition that resulted in the extinction of the giant Xenarthrans? Did man play a direct or indirect role in the extinction of these great South American mammals? New Pleistocene/Holocene discoveries and new dating necessary to answer to these questions.

\section{Acknowledgments}

We would like to thank Drs. R. Hulbert and B. MacFadden (UF), J. J. Flynn and B. Simpson (FMNH), Drs. K. L. Seymour and G. De Iuliis (ROM), Dr. N. Valencia (MUSM), A. A. Aliaga Apaéstegui (Mayor of Celendín), T. Quiroz (Mayor of Chingas), the INC, and the paleontological mission of the IPGQ for allowing us to examine specimens under their care. Special thanks are due to Drs. G. De Iuliis (ROM) and B. Shockey for sharing with us unpublished data about Xenarthra, Dr. L. Werdelin (NMR) for giving information about Casa del Diablo material conserved in Swedish Museum of Natural History, Drs. H. G. McDonald (GRD-NPS) and C. Argot (MNHN) for helpful corrections and comments to an earlier version of the text, and the two reviewers Dr. C. de Muizon (MNHN) and Lic. A. A. Carlini (MLP) for criticisms of the manuscript. Field trips were financed by IFEA and MAE (2000-2001 and 2003 grant), MUSM, and MNHN (2000-2001). 


\section{References Cited}

ARGOT, C. \& PUJOS, F., 2003 - Functional anatomy of two megalonychid sloths (Xenarthra, Mammalia). Terra Nostra, 5: 23A.Congress "Endogene und Exogene Hintergründe der Biodiversität", Mainz, Germany, 29/9 - 3/10/2003.

BRYAN, A. L., 1973 - Paleoenvironments and cultural diversity in late Pleistocene in South America. Quaternary Research, 3: 237-256.

BUFFETAUT, E. \& HOFFSTETTER, R., 1977 - Découverte d'un crocodilien Sebecus dans le Miocène du Pérou oriental. Comptes Rendus de l'Académie des Sciences, 284: 16631666.

CALDAS VIDAL, J., 1978 - Geología de los Cuadrángulos de San Juan, Acarí y Yauca, 78p.; Lima: Instituto de Geología y Minería Edición, (30).

CARDICH, A., 1973 - Exploración en la caverna de huargo, Perú. Revista del Museo Nacional de Lima, 39: 11-47.

CASA-VILCA, A., 1958 - Una exploración paleontológica y arqueológica en Ica. Los primeros fósiles vertebrados. Boletín de la Sociedad Geográfica de Lima 75(3-4): 54-62.

CHAUCHAT, C., 1998 - Sitios arqueológicos de la zona de Cupisnique y margen derecha del valle de Chicama, 169 p.; Trujillo: IFEA-INC sede La Libertad.

CHURCHER, C. S., 1959 - Fossil Canis from the Tar pits of La Brea, Peru. Science, 130: 564565.

CHURCHER, C. S., 1962 - Odocoileus salinae and Mazama sp. from the Talara Tar-seeps, Peru. Life Sciences Division, Royal Ontario Museum - University of Toronto, 57: 1-27.

CHURCHER, C. S., 1965 - Camelid material of the genus Paleolama Gervais from the Talara Tar-seeps, Peru, with a description of a new subgenus, Astylolama. Proceedings of the Zoological Society of London, 145(2): 161-205.

CHURCHER, C. S., 1966 - The insect fauna from the Talara Tar-seeps, Peru. Canadian Journal of Zoology, 44: 985-993.

CHURCHER, C. S. \& ZYLL DE JONG, Van C. G., 1965 - Conepatus talarae n. sp. from the Talara Tar-seeps, Peru. Life Sciences Division, Royal Ontario Museum - University of Toronto, 62: 1-15.

COLLINA-GIRARD, J., GUADELLI, J.-L. \& USSELMAN, P., 1992 - Mammifères disparus et premières occupations humaines. L'exemple nord péruvien du désert de Cupisnique. In: Colloque Déserts: passé, présent, futur, actes du $116^{\mathrm{eme}}$ Congrès National des Sociétés Savantes: 111-132; Chambéry.

DE IULIIS, G., 1996 - A systematic review of the Megatheriinae (Mammalia: Xenarthra: Megatheriidae). Unpublished PhD. Thesis, University of Toronto, Toronto, $719 \mathrm{p}$.

EATON, G. F., 1914 - Vertebrate fossils from Ayushbamba, Peru. American Journal of Science, 37(218): 141-154.

EDMUND, A. G., 1987 - Evolution of the genus Holmesina (Pampatheriidae, Mammalia) in Florida, with remarks on taxonomy and distribution. Pearce-Sellards Series, Texas Memorial Museum, (45): 1-20.

ENGEL, F., 1970 - La grotte du Megatherium et les écologies du Haut-Pliocène Péruvien. Semiotica, (1): 413-436.

ESTEBAN, G. I., 1996 - Revisión de los Mylodontinae cuaternarios (Edentata-Tardigrada) de Argentina, Bolivia y Uruguay. Sistemática, filogenia, paleobiología, paleozoogeografía y paleoecología. Doctorado inédito en Ciencias Naturales "Orientación Zoología", Universidad Nacional de Tucumán, Tucumán, 314 p.

FALGUÈRES, C., FONTUGNE, M., CHAUCHAT, C. \& GUADELLI, J.-L., 1994 - Datations radiométriques de l'extinction des grandes faunes pléistocènes au Pérou. Comptes Rendus de l'Académie des Sciences, série 2, 319: 261-266. 
FRAILEY, C. D., 1986 - Late Miocene and Holocene mammals, exclusive of the Notongulata, of the Río Acre region, western Amazonia. Contributions in Science, (374): 1-46.

GAUDIN, T. J. \& DE IULIIS, G., 1999 - The late Miocene sloth Nothropus priscus, with comments on the phylogeny of the Nothrotheriidae. Journal of Vertebrate Paleontology, 19 (supplement to 3): 46A.

GERVAIS, P., 1855 - Recherches sur les mammifères fossiles de l'Amérique méridionale. Zoologie de l'Expédition Castelnau, $4{ }^{\text {ème }}$ série, 1(1): 1-63.

GERGORY, H. E., 1914 - Geologic reconnaissance of the Ayushbamba (Peru) fossil beds. American Journal of Science, 4(37): 125-140.

HOFFSTETTER, R., 1952 - Les mammifères pléistocènes de la République de l'Équateur. Mémoires de la Société Géologique de France, 31(66): 391 p.

HOFFSTETTER, R., 1968 - Un gisement de vertébrés tertiaires à Sacaco (Sud-Pérou), témoin néogène d'une migration de faunes australes au long de la côte occidentale sudaméricaine. Comptes Rendus de l'Académie des Sciences, série D, 267: 1273-1276.

HOFFSTETTER, R., 1970 - Vertebrados cenozóicos y mamíferos cretácicos del Peru. Actas IV Congreso Latinoamericano de Zoología, 2: 971-983; Caracas.

HOFFSTETTER, R., 1986 - High Andean mammalian faunas during the Plio-Pleistocene. In: High altitude tropical biogeography (Vuilleumier, F. \& Monasterio, M., eds.): 219-245, Number 9, New York: Oxford University Press, Inc.

KALAFATOVICH, V., 1955 - El fósil glyptodonte hallado en el Cuzco. Revista de la Universidad San Antonio Abad del Cuzco, (108): 150-156.

KRAGLIEVICH, L., 1926-Presencia del género “Nothrotherium”'Lydek. (= "Coelodon”'Lund) en la fauna pampeana "Nothrotherium torresi", n. sp.. Revista del Museo de La Plata, 29: 169-186.

KRAGLIEVICH, L., 1931 - Un nothrotherio pampeano gigantesco - Nothrotherium roverei Kragl.. Anales del Museo Nacional de Historia Natural "Bernardino Rivadavia", 36: 503-513.

LEMON, R. R. H. \& CHURCHER, C. S., 1961 - Pleistocene geology and paleontology of the Talara region, northwest Peru. American Journal of Science, 259: 410-429.

LISSON, C. J., 1912 - Un esqueleto antidiluviano en la sierra de la Viuda en la provincia de Yauli. El megaterio de Yantac. Boletín de la Sociedad Geográfica de Lima, 28: 126-129.

MAGUIÑA, T., 1988 - Fósiles del Alto Marañón, 122 p.; Lima: Editorial Impulso Ed.

MARSHALL, L. G., HOFFSTETTER, R. \& PASCUAL, R., 1983 - Mammals and stratigraphy: geochronology of the continental mammal-bearing Tertiary of South America. Paleovertebrata, 93 p. Mémoire Extraordinaire.

MARSHALL, L. G., BERTA, A., HOFFSTETTER, R., PASCUAL, R., BOMBIN, M. \& MONES, A., 1984 - Mammals and stratigraphy: geochronology of the continental Í mammal-bearing Quaternary of South America. Paleovertebrata, 76 p. Mémoire Extraordinaire.

MARTÍNEZ, J.-N. \& JACAY, J., 2000 - Evolución sedimentológica y paleontológica del paleodelta del Chira (Departamento de Piura) durante el Pleistoceno, datos preliminares. In: X Congreso Peruano de Geología: 37R; Lima.

MacPHEE, R. D. E. \& ITURRALDE-VINENT, M. A., 1994 - First Tertiary land mammal from Greater Antilles: an Early Miocene sloth (Mammalia, Megalonychidae) from Cuba. Bulletin of the American Museum of Natural History, (3094): 1-13.

McDONALD, H. G., 1987 - A systematic review of the Plio-Pleistocene scelidotherine ground sloth (Mammalia: Xenarthra: Mylodontidae). Unpublished PhD. Thesis, University of Toronto, Toronto, $478 \mathrm{p}$.

McDONALD, H. G. \& MUIZON, C. de, 2002 - The cranial anatomy of Thalassocnus (Xenarthra, Mammalia), a derived nothrothere from the Neogene of the Pisco Formation (Peru). Journal of Vertebrate Paleontology, 22(2): 349-365. 
McKENNA, M. C. \& BELL, S. K., 1997 - Classification of mammals about the species level, 631p.; New York: Colombia University Press.

McNEISH, R. S., 1971 - Early man in the Andes. Scientific American, 224(4): 36-46.

McNEISH, R. S., BERGER, R. \& PROTSCH, R., 1970 - Megafauna and man from Ayacucho, Highland Peru. Science, 168(3934): 975-977.

McNEISH, R. S., PATTERSON, T. C. \& BROWMAN, D. L., 1975 - The central Peruvian prehistoric interaction sphere. Papers R. S. Peabody of Archaeology, 7: 1-97.

MONES, A., 1986 - Acremylodon a new name for Stenodon Frailey, 1986 (Mammalia: Edentata, Mylodontidae). Comunicaciones Paleontológicas del Museo de Historia Natural de Montevideo, 1(16): 227-228.

MUIZON, C. de \& McDONALD, H. G., 1995 - An aquatic sloth from the Pliocene of Peru. Nature, 375: 224-227.

MUIZON, C. de, McDONALD, H. G., SALAS, R. \& URBINA, M., 2003 - A new early species of the aquatic sloth Thalassocnus (Mammalia, Xenarthra) from the late Miocene of Peru. Journal of Vertebrate Paleontology, 23(4): 886-894.

MUIZON, C. de, McDONALD, H. G., SALAS, R. \& URBINA, M., 2004-The youngest species of the aquatic sloth Thalassocnus, and a reassessment of the relationships of the Nothrothere sloths (Mammalia, Xenarthra). Journal of Vertebrate Paleontology, 24(2): 390-400.

NORDENSKIÖLD, E., 1905 - Exploration scientifique au Pérou et en Bolivie (1904-1905). La Géographie, Bulletin de la Société de Géographie, 12(5): 289-296.

NORDENSKIÖLD, E., 1908 - Ein neuer Fundort für sâugetierfossilien in Peru. Arkiv für Zoologi, 4(11): 13-21.

PATTERSON, B. \& PASCUAL, R., 1972 - The fossil Mammal Fauna of South America. In: Evolution, Mammals, and Southern Continents (Keast, A., Erk, F. C. \& Glass, B., eds.): 247-309; Albany: State University of New York Press.

PASCUAL, R. \& ODREMAN RIVAS, O. E., 1973 - Estudio del material osteológico extraído de la caverna de Huargo, departamento de Huánuco, Perú, Appendix 2 to Cardich A. Revista del Museo Nacional de Lima, 39: 31-39.

PUJOS, F., 2000 - Scelidodon chiliensis (Xenarthra, Mammalia) du Pléistocène terminal de "Pampa de los Fósiles". Quaternaire, 11(3-4): 197-206.

PUJOS, F., 2001 - A new megatheriine genus from the latest Pleistocene of Northern Peru. Journal of Morphology 248(3): $273 \mathrm{~A} .6^{\text {th }}$ International Congress of Vertebrate Morphology, Jena, Germany, 21-26 July 2001.

PUJOS, F., 2002a-Estudio geológico, estratigráfico, sedimentológico y palinológico de la cueva de mamíferos del Pleistoceno de Santa Rosa (Perú): interpretación paleo-ambiental. Bulletin de l'Institut Français d'Études Andines, 31(1): 101-113.

PUJOS, F., 2002b - Contribution à la connaissance des Tardigrades (Mammalia: Xenarthra) du Pléistocène péruvien: systématique, phylogénie, anatomie fonctionnelle et extinction. Unpublished PhD Dissertation, Muséum national d'Histoire naturelle, Paris, 513 p.

PUJOS, F., DE IULIIS, G., WERDELIN, L. \& ARGOT, C., 2004 - An original Lujanian Megatheroidea from Peru: implications concerning the locomotion of sloths. Journal of Morphology, 260(3): 320A. $7^{\text {th }}$ International Congress of Vertebrate Morphology, Boca Raton, Florida, USA, 27 July 2004- 01 August 2004.

PUJOS, F. \& SALAS, R., 2002 - Preliminary observations of a new Pleistocene Megatherium (Mammalia: Xenarthra: Megatheriidae) from the Peruvian coast. Ameghiniana, 38(4): 40R. Reunión Anual de Comunicaciones de la Asociación Paleontológica Argentina, Diamante.

PUJOS, F. \& SALAS, R., 2004 - A new species of Megatherium (Mammalia: Xenarthra: Megatheriidae) from the Pleistocene of Sacaco and Tres Ventanas, Peru. Palaeontology 47(3): 579-604. 
PUJOS, F., SALAS, R. \& MATTOS, J., 2002 - Andean lineage of Pleistocene Megatherium: geographical implication. Journal of Vertebrate Paleontology, 22(supplement to 3): 97A. $62^{\text {nd }}$ Annual Meeting of The Society of Vertebrate Paleontology, October 9-12, 2002, Norman, Oklahoma, USA.

RAIMONDI, A., 1898 - Mandíbula inferior de "Mastodon andium" hallado en un terreno cerca de la desembocadura del río Moyobamba al Huallaga. Boletín de la Sociedad Geográfica de Lima, 7(10): 406-409.

RAMíREZ PAREJA, J. A., 1958 - Mamíferos fósiles del Dpto. Del Cuzco. Thesis, Universidad de Cuzco, Cuzco.

RANGEL, C. \& ROMERO, L., 1985 - Vertebrados fósiles. De Re Metallica, “Julio-Agosto": 7-9.

SALAS, R., PUJOS, F. \& MUIZON, C. de, 2002 - Anatomical connection of lunula and cyamoflabella in a fossil ground sloth (Thalassocnus natans) and functional interpretation. In:Extended abstracts of the $3^{\text {rd }}$ European Meeting on the Paleontology and Stratigraphy of Latin America: 113-116; Toulouse.

SALAS, R. \& STUCCHI, M., 2002 - Reporte preliminar de Lama guanicoe (Mammalia, Artiodactyla, Camelidae) en el Pleistoceno superior de Aguada de Lomas, Arequipa. In: XI Congreso Peruano de Geología: 218R; Lima.

SALAS, R., STUCCHI, M. \& DEVRIES, T., 2003 - Presence of Plio-Pleistocene Palaeolama sp. (Artiodactyla: Camelidae) on the Southern Coast of Peru. Bulletin de l'Institut Français d'Études Andines, 32(2): 347-359.

SPILLMANN, F., 1949 - Contribución a la Paleontología del Perú. Una Mamifauna Fósil de la Región del Río Ucayali. Publicaciones del Museo de Historia Natural "Javier Prado", Serie C. Geología y Paleontología, 1(1): 1-40.

ST-ANDRÉ, P.-A. \& DE IULIIS, G., 2001 - The smallest and most ancient representative of the genus Megatherium Cuvier, 1796 (Xenarthra, Tardigrada, Megatheriidae), from the Pliocene of the Bolivian Altiplano. Geodiversitas, 23(4): 625-645.

UBBERLOHDE-DOERING, H., 1939 - Berich über archäologische Feldarbeiten in Peru. II. Ethnos, 24(1-2): 1-32.

VIZCAÍNO, S. F. \& SCILLATO-YANÉ, G. J., 1995 - An Eocene Tardigrade (Mammalia, Xenarthra) from Seymour Island, West Antarctica. Antarctic Science, 7(4): 407-408.

WILLARD, B., 1966 - The Harvey Bassler Collection of Peruvian Fossils, 255 p.; Lehigh. 
Table 1 - Mio-Pliocene Xenarthra from Peru.

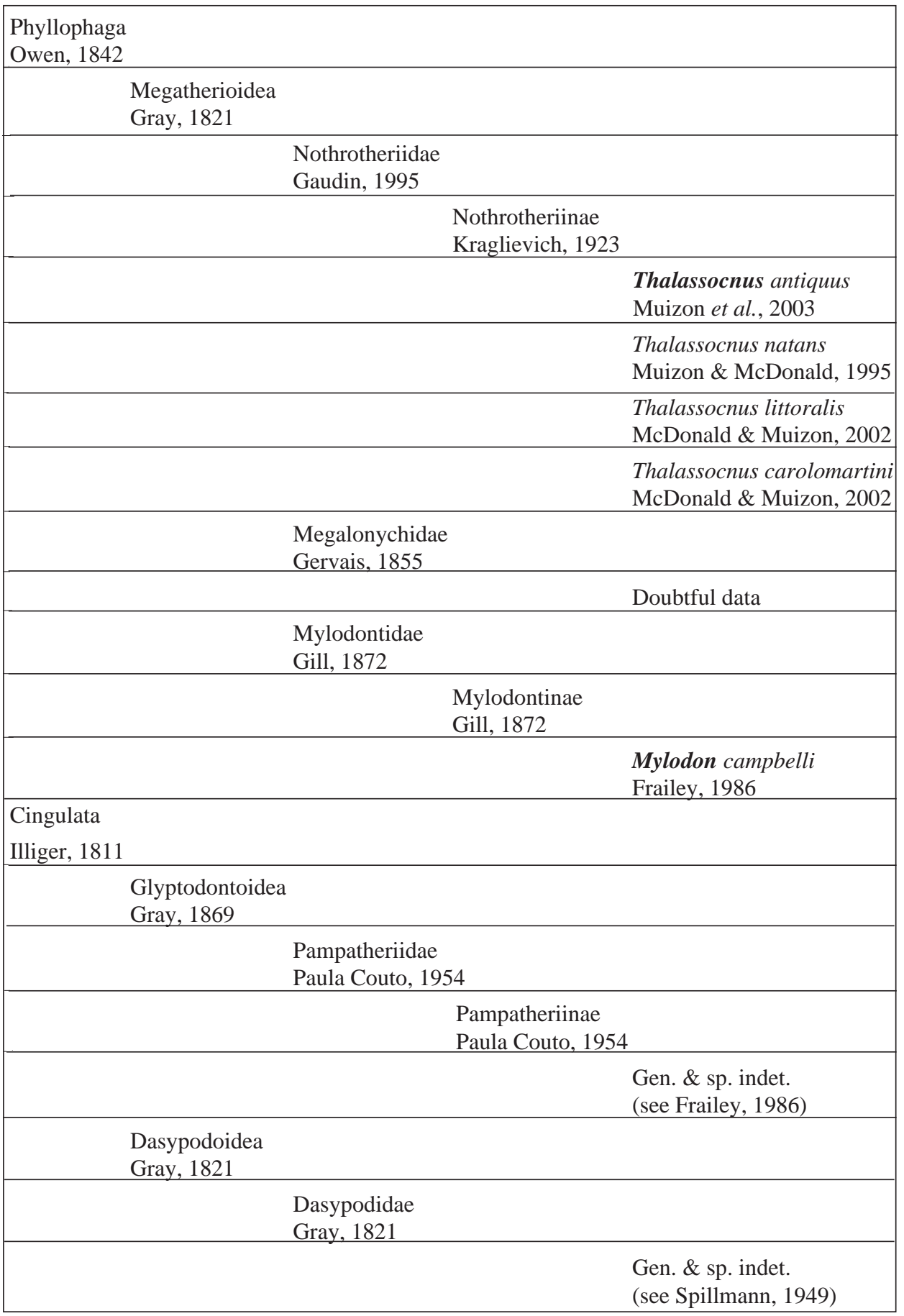


Table 2 - Pleistocene-Holocene Xenarthra from Peru.

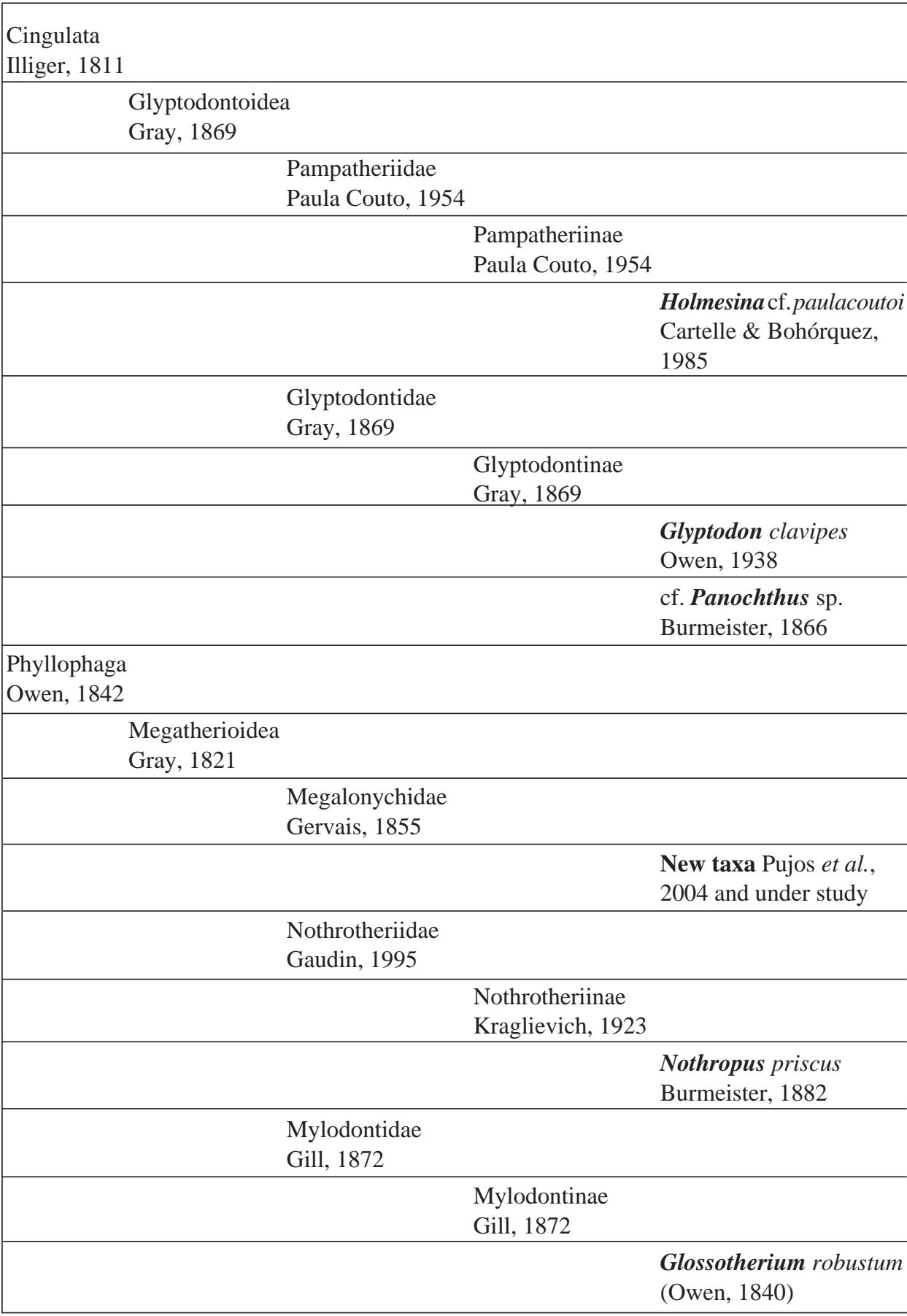




\begin{tabular}{|c|c|c|}
\hline \multirow{2}{*}{\multicolumn{2}{|c|}{$\begin{array}{l}\text { Scelidotheriinae } \\
\text { Ameghino, } 1904\end{array}$}} & \\
\hline & & $\begin{array}{l}\text { Scelidodon chiliensis } \\
\text { (Lydekker, 1886) }\end{array}$ \\
\hline \multicolumn{3}{|l|}{$\begin{array}{l}\text { Megatheriidae } \\
\text { Owen, } 1843\end{array}$} \\
\hline \multicolumn{3}{|c|}{$\begin{array}{l}\text { Megatheriinae } \\
\text { Gill, } 1872\end{array}$} \\
\hline & & $\begin{array}{l}\text { Eremotherium laurillardi } \\
\text { (Lund, 1842) }\end{array}$ \\
\hline & & $\begin{array}{l}\text { Megatherium } \\
\text { (Pseudomegatherium) } \\
\text { tarijense Gervais \& } \\
\text { Ameghino, } 1880\end{array}$ \\
\hline & & $\begin{array}{l}\text { Megatherium } \\
\text { (Pseudomegatherium) } \\
\text { elenense (Hoffstetter, 1949) }\end{array}$ \\
\hline & & $\begin{array}{l}\text { Megatherium } \\
\text { (Pseudomegatherium) } \\
\text { urbinai Pujos \& Salas, 2004 }\end{array}$ \\
\hline & & $\begin{array}{l}\text { Megatherium } \\
\text { (Pseudomegatherium) sp. } \\
\text { nov. Pujos, 2001,2002b, and } \\
\text { under study }\end{array}$ \\
\hline
\end{tabular}


FIGURES 


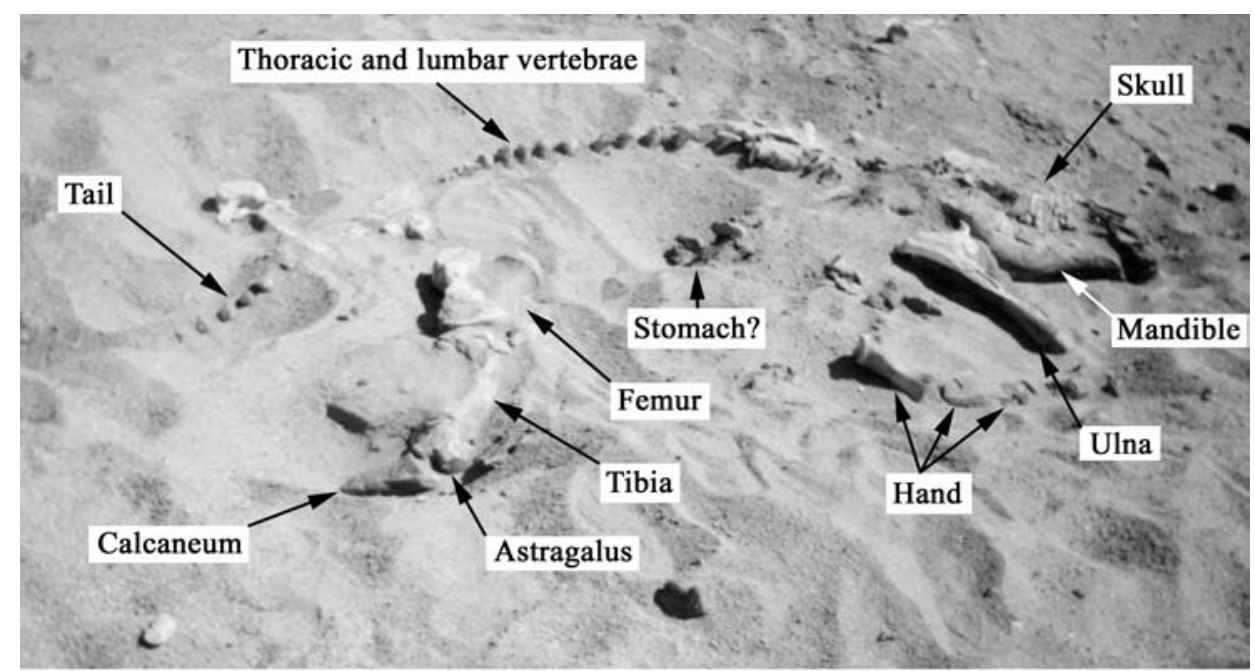

A

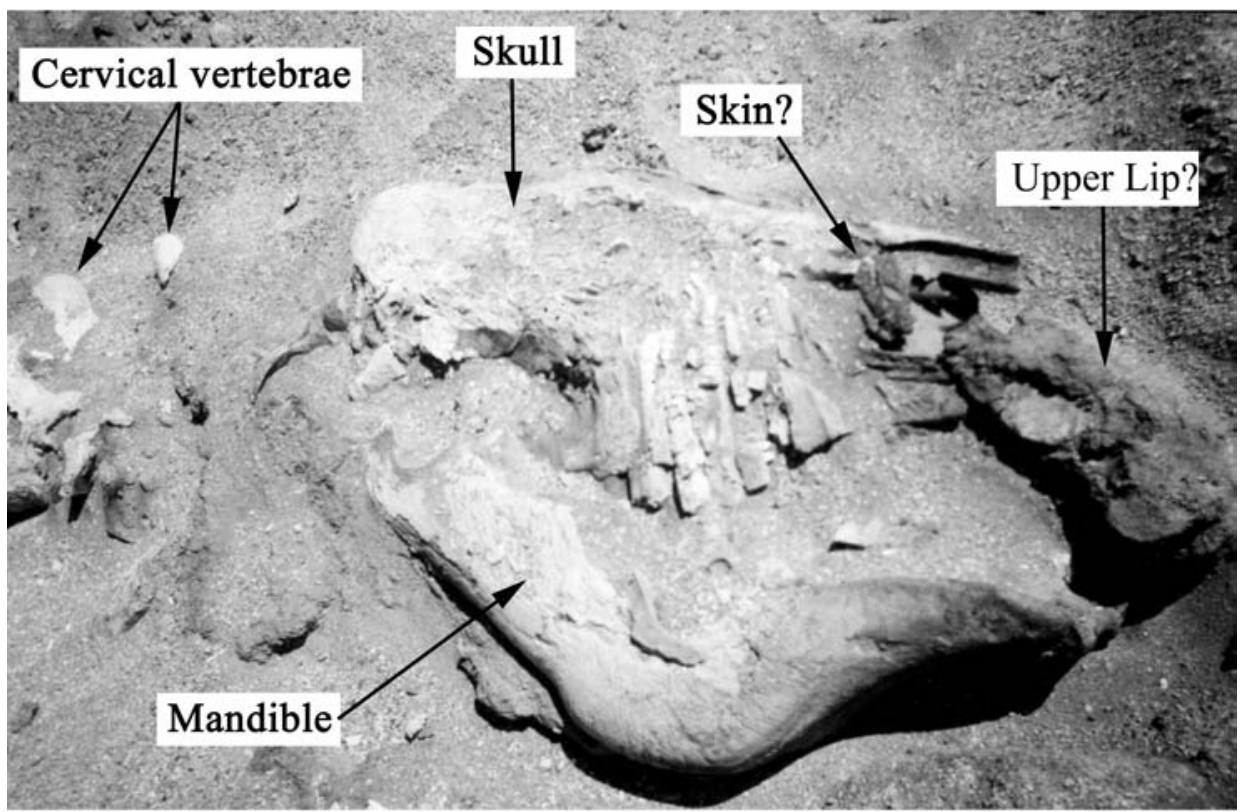

B

Fig. 2 - Skeleton of Megatherium Pseudomegatherium cf. urbinai from Uyujalla (Ocucaje). A: lateral view of the skeleton; B: lateral view of the skull and the mandible. 

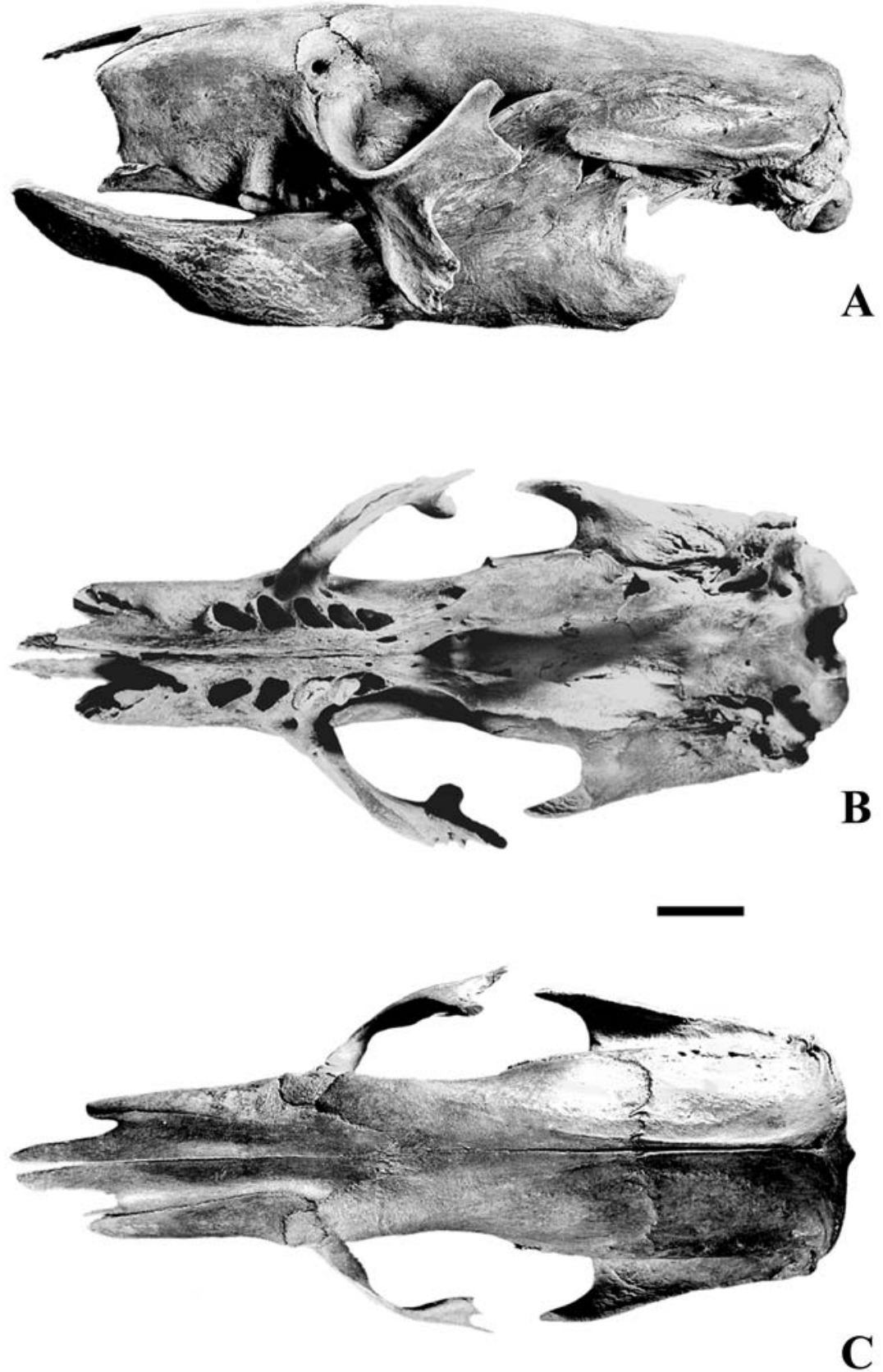

Fig. 3 - Skull of Scelidodon chiliensis from Chingas (conserved at the Chingas council, without reference number) in lateral (A): ventral (B), and dorsal (C) views. Scale bar equals $5 \mathrm{~cm}$. 
Fig. 4 - Scelidodon chiliensis from Pampa de los Fósiles, Cerro de Pasco, and Tres Ventanas. A: right scapula (MNHN CPN 16) in lateral view (anterior towards top); $B$ : right humerus (juvenile specimen, UNA with the same reference number than UNA V2642 of $M$. urbinai sp. nov.) in anterior view (medial towards right); C-D: left radius (MUSM 122') in posterior and anterior views (medial towards right); E: right femur (MNHN CPN 16) in posterior view (proximal towards top); F: left tibia, fibula and astragalus (MNHN CPN 16) in anatomical position in anterior view (proximal towards top); G: right damaged calcaneum (HDD PV22-44-U6) in dorsal view (posterior towards top). Scale bar equals $5 \mathrm{~cm}$. 


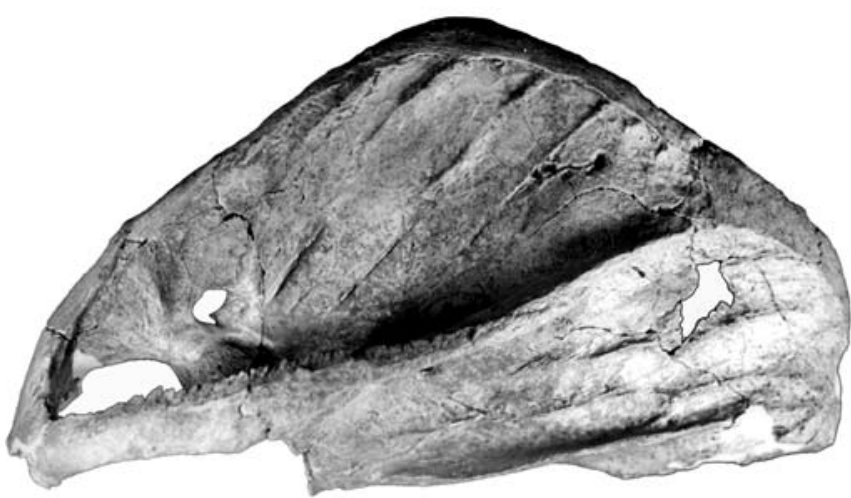

A
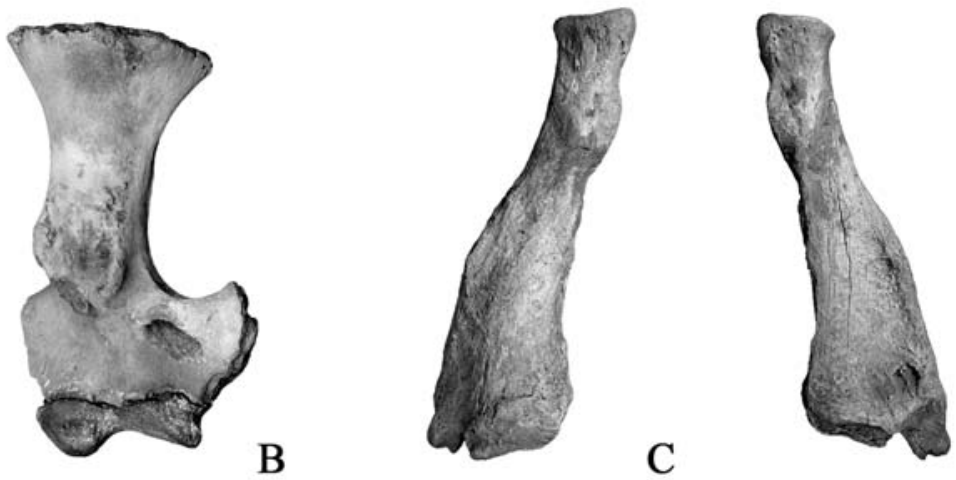

C
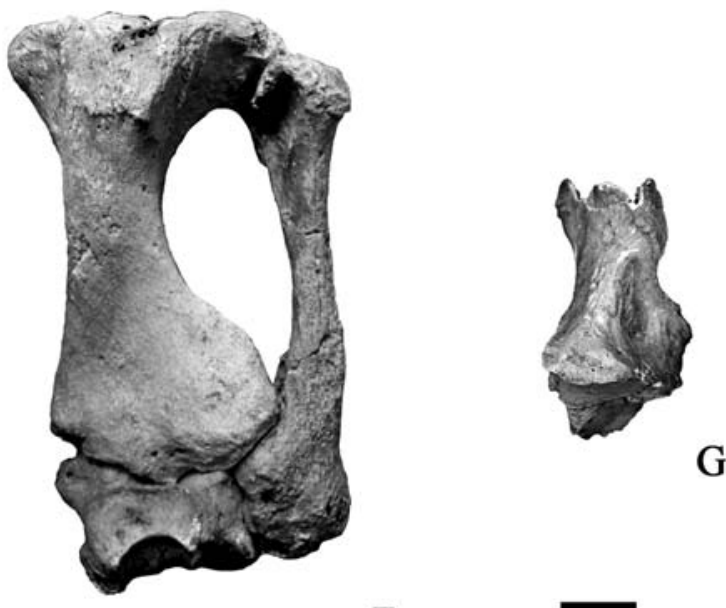

E

F 
Fig. 5 - Eremotherium laurillardi from Pampa de los Fósiles, Tumbes and La Huaca. A: skull (MUSM 108) in ventral view (anterior towards left); B-C: skull (first specimen of HDD PV22-40) in ventral (anterior portion of the skull) and dorsal (posterior portion of the skull) views (anterior towards left); D: skull (second specimen of HDD PV22-40) in dorsal view (anterior towards left); E-F: right dental (MUSM 109) in occlusal and medial views (anterior towards left); G: right dental (first specimen of HDD PV22-40) in lateral view (anterior towards left); H-I: dental in occlusal and medial view (anterior towards left); J-K: molariform tooth (HDD PV22-40) in profile and open (a pathological nodule of vasodentine can be observed inside). Scale bar equals $5 \mathrm{~cm}$. 

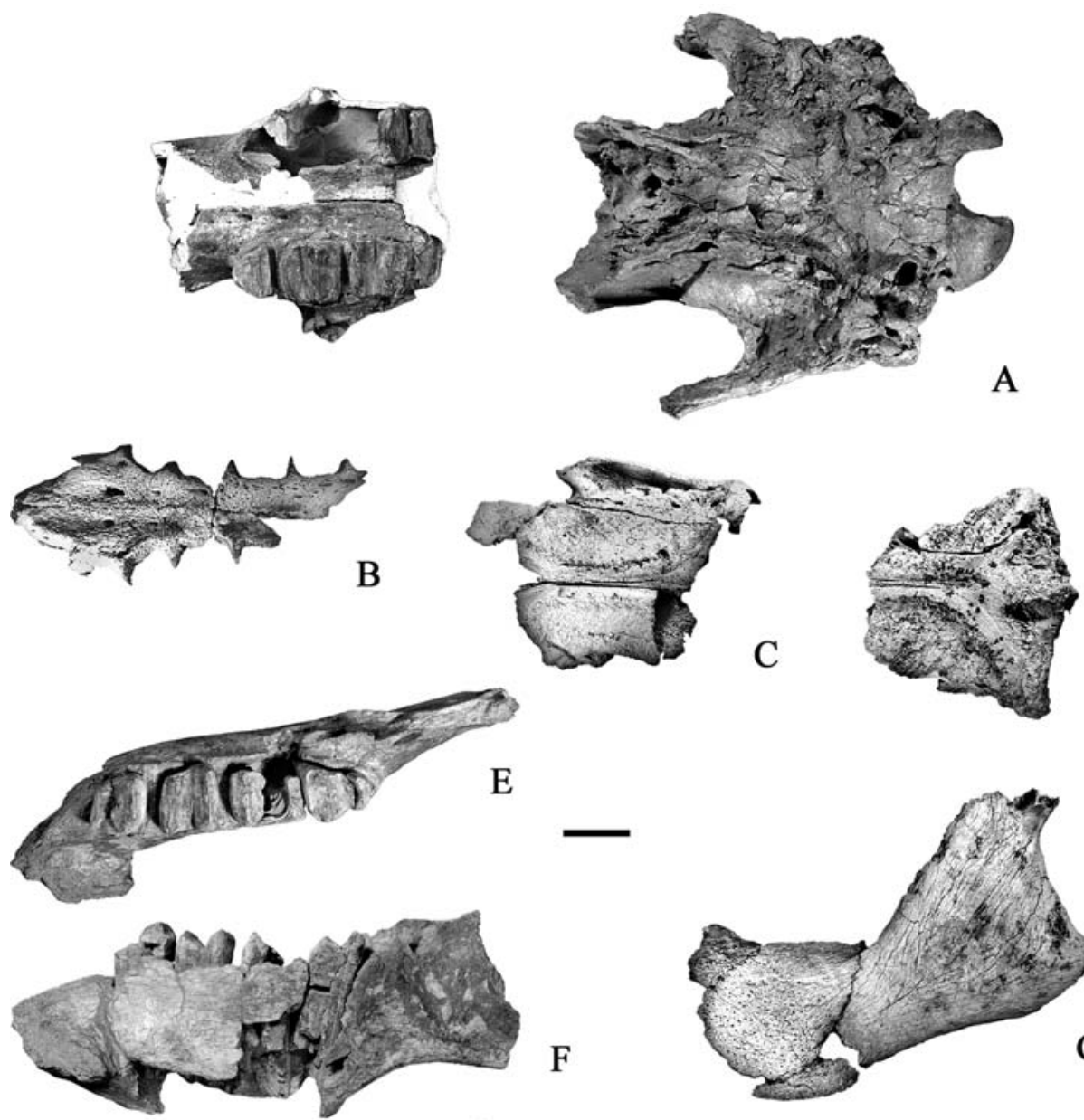

$\mathrm{F}$
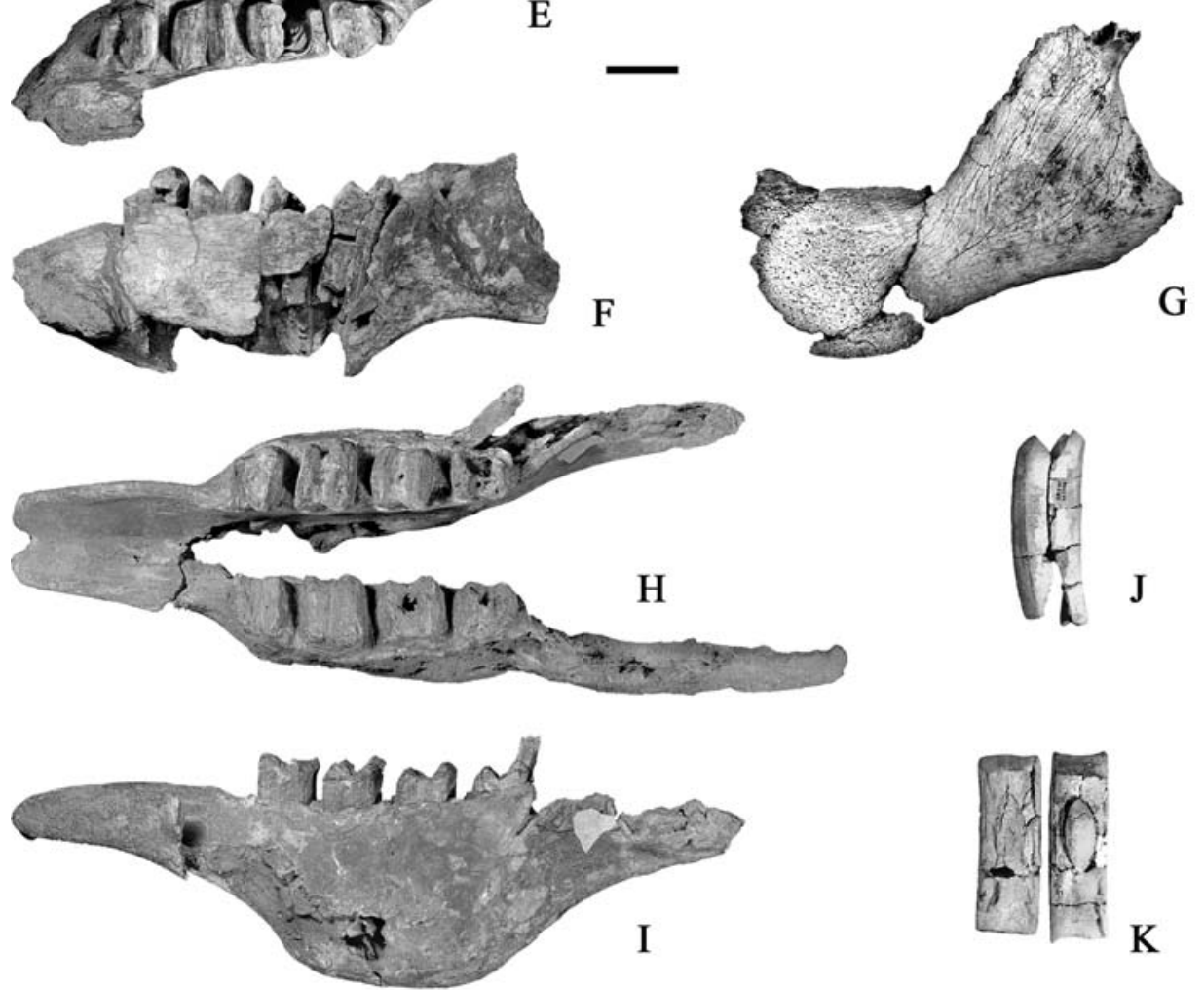

K 
Fig. 6 - Eremotherium laurillardi from Pampa de los Fósiles and Tumbes. A: atlas (HDD PV22-44-U9) in ventral view (anterior towards bottom); B: axis (MUSM 101) in anterior view (dorsal towards top); C: left clavicle (HDD PV22-44-U9) in dorsal view (posterior towards bottom); $D$ : right humerus in anterior view (lateral towards left); E: proximal epiphysis of the right ulna (MUSM 100) in lateral view (proximal towards top); F: proximal extremity of the left femur (HDD PV22-44-U9) in anterior view (proximal towards top); G: left partial tibia and fibula (HDD PV22-44-U9) in anterior view (proximal towards top); H: right calcaneum (MUSM 122) in dorsal view (anterior towards left); I-K: left astragalus (HDD PV22-44-U9) in plantar (posterior towards top), lateroplantar (anterior towards left) and anterodistal (medial towards left) views. Scale bar equals $5 \mathrm{~cm}$. 


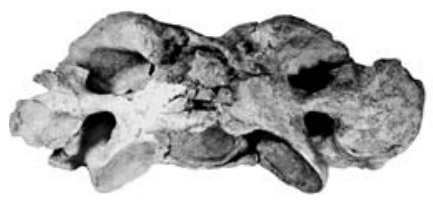

A
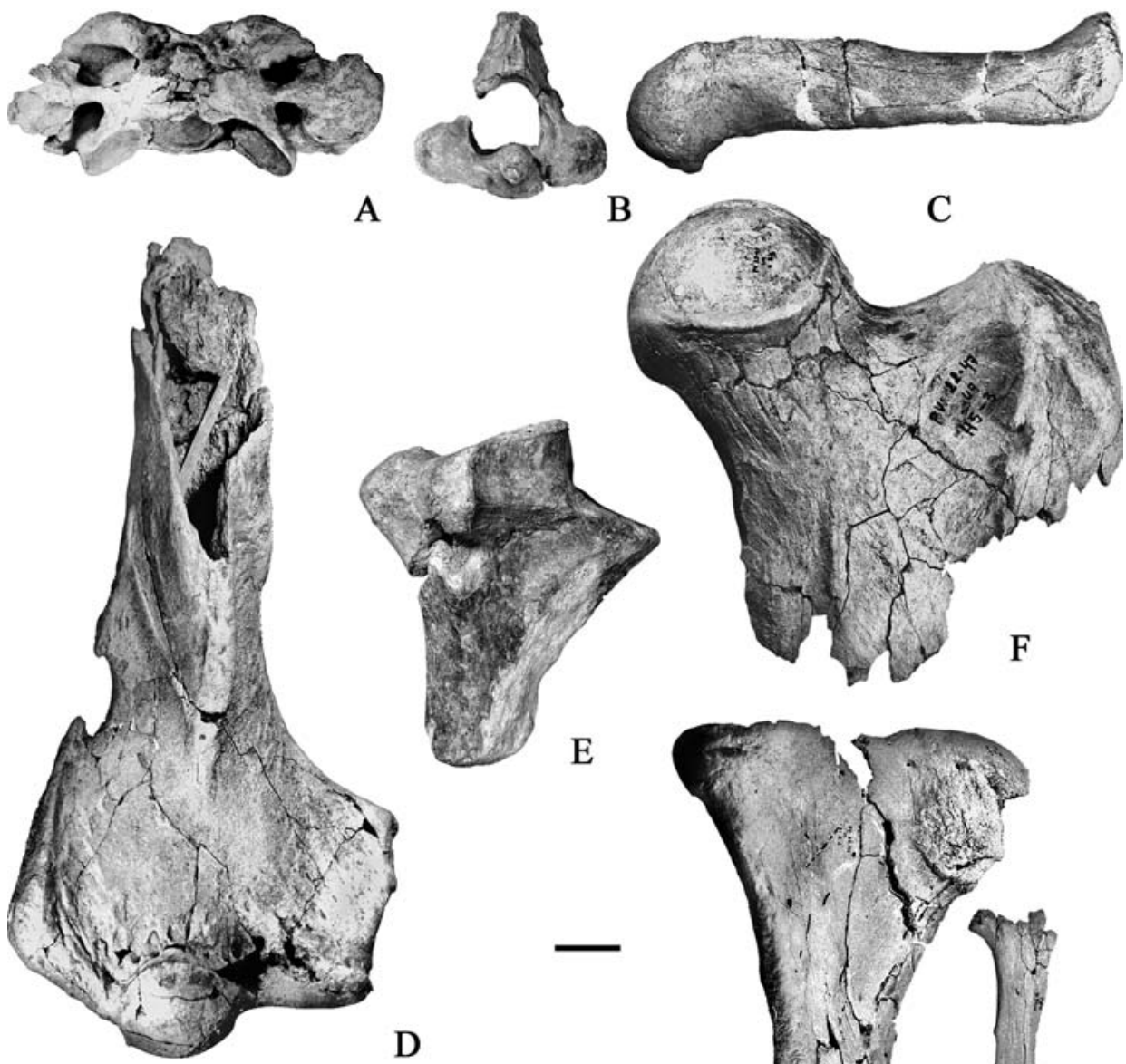

B

C
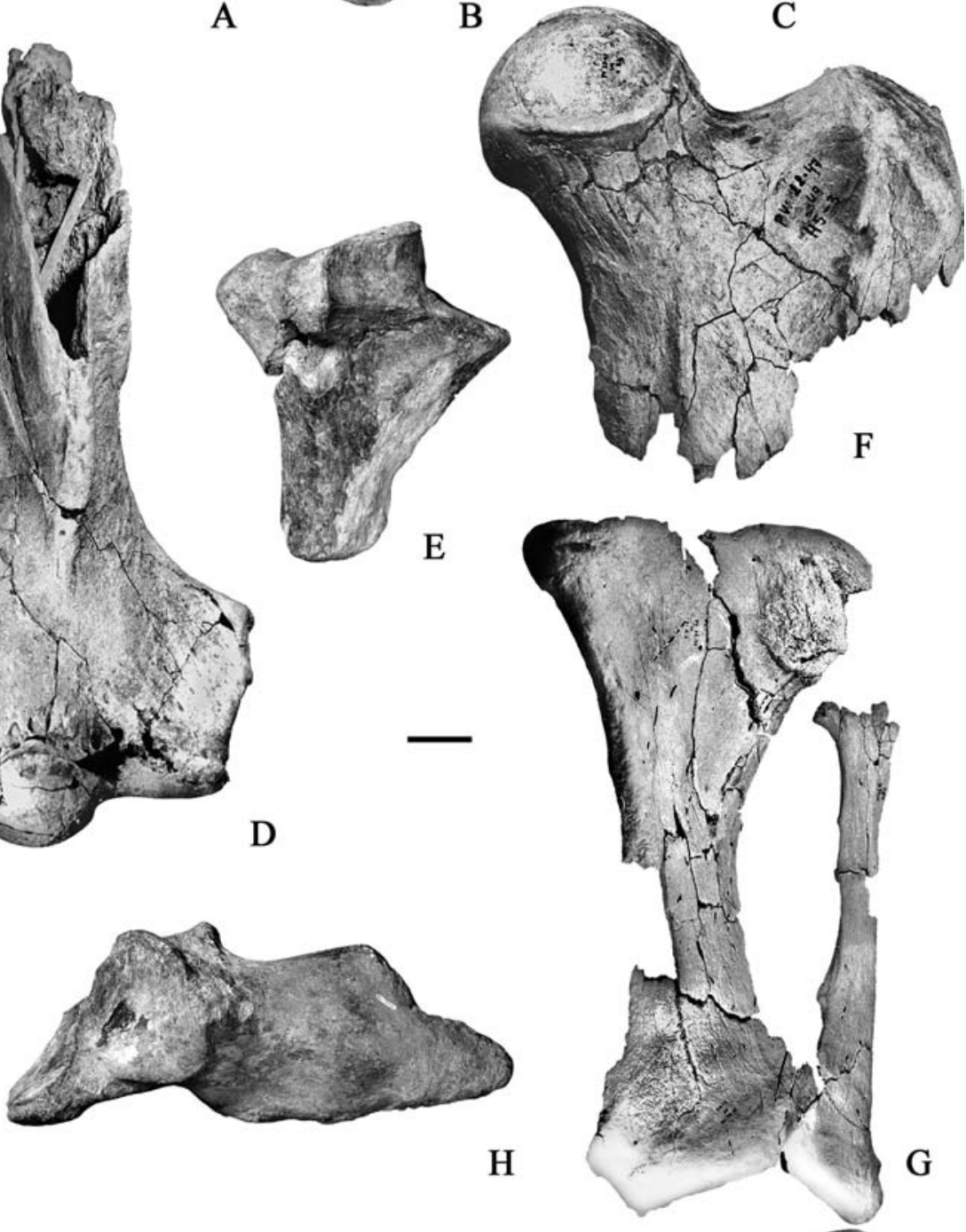

G
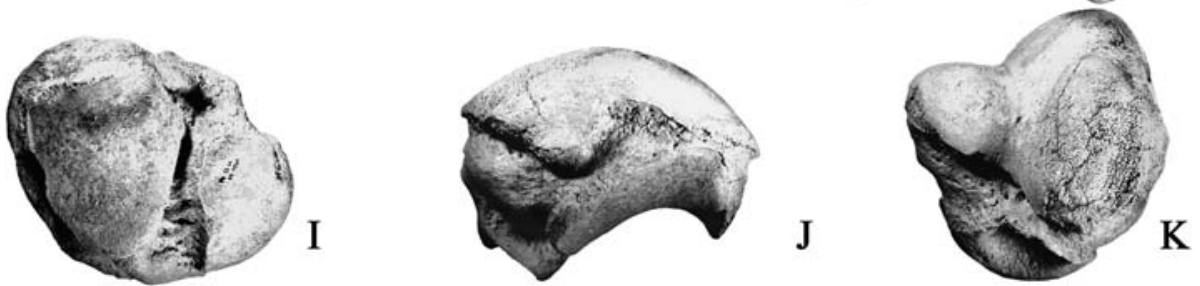
Fig. 7 - Megatherium (Pseudomegatherium) elenense from Talara (ROM material) and Cerro de Pasco (MUSM material). A-B: dental (ROM 3756) in occlusal and left lateral views (anterior towards right); C: partial left manus (MUSM 134) in dorsal view (proximal towards top); D: left Mc III (ROM 35033) in dorsal view (proximal towards top); E: anterior portion of left femur (MUSM 134) in posterior view; F: left calcaneum (ROM 2697) in dorsal view (anterior towards left); G-H: pelvis (MUSM 157) in anterior (dorsal towards top) and ventral (anterior towards top) views; I-K and L-N: left astragali (ROM 1698 and MUSM 134 respectively) in anterior (I, L: dorsal towards top), dorsolateral (J, M: medial towards left), and plantar (K, N: posterior towards top) views. Scale bars equals $5 \mathrm{~cm}$. 

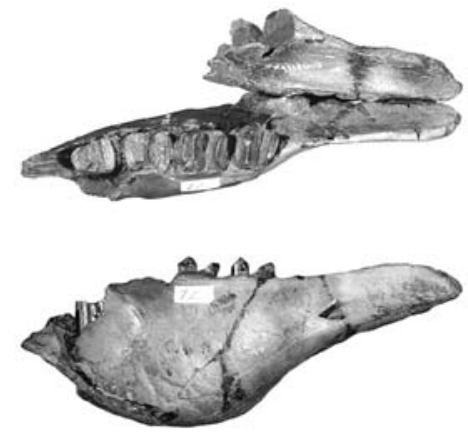

B

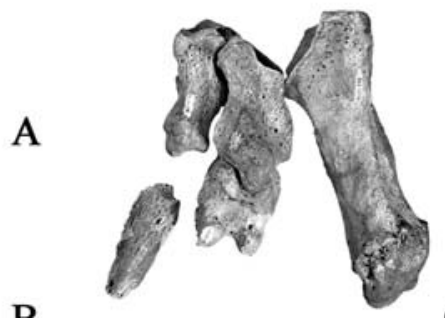

C D
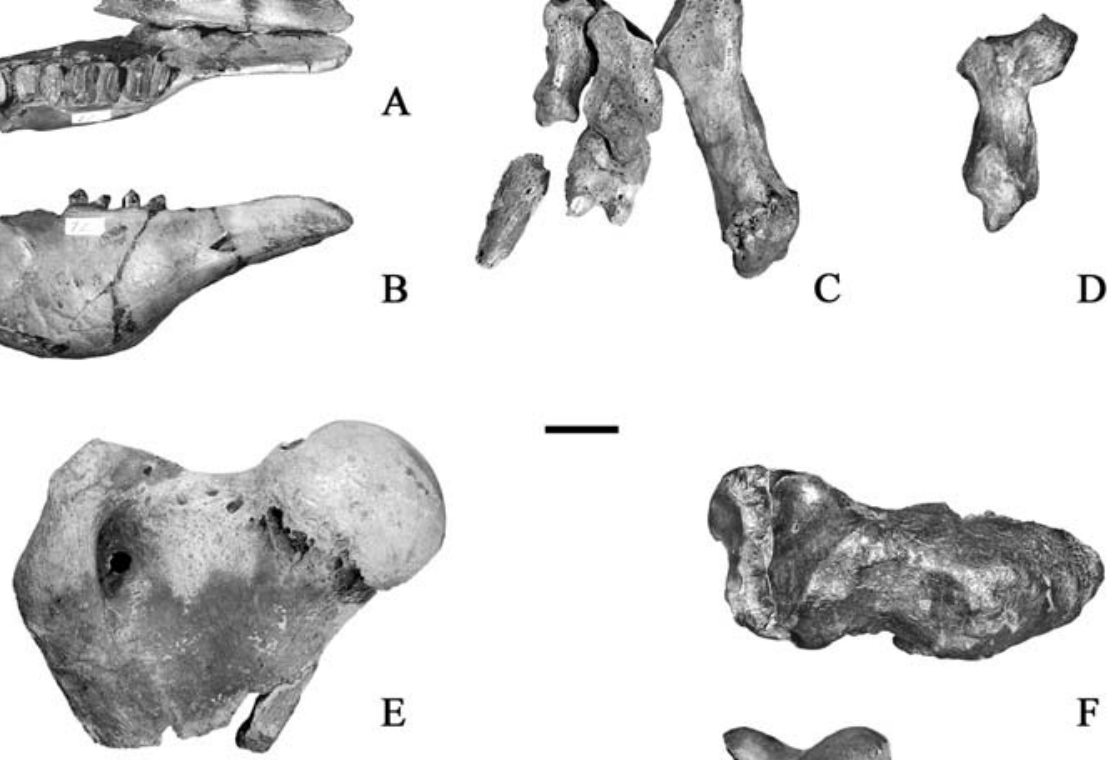

E
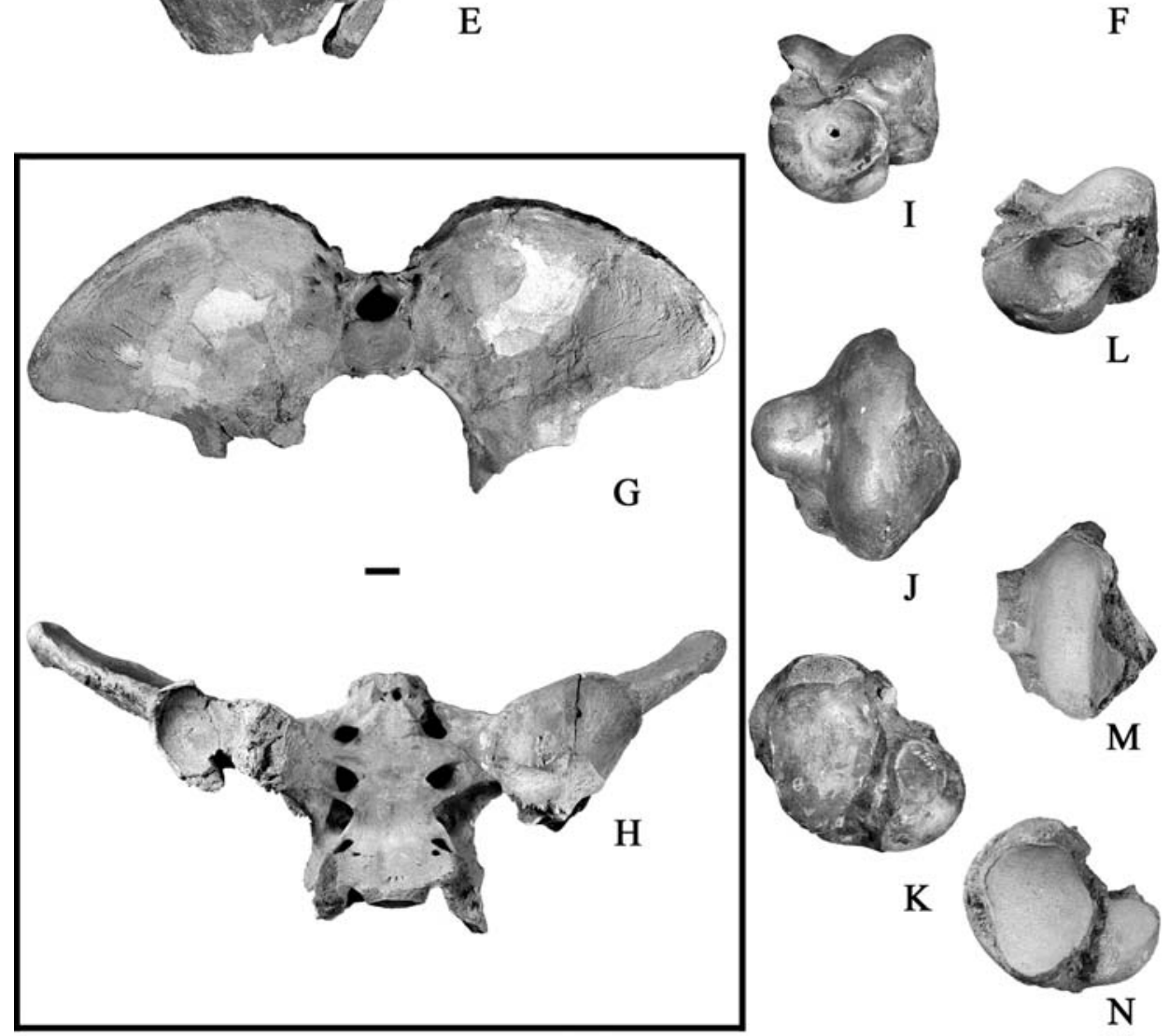
Fig. 8 - Photographs of selected elements of Megatherium (Pseudomegatherium) urbinai (after Pujos \& Salas, 2004). A: left manus in dorsal view (proximal towards top, medial towards left); B: right foot in dorsal view (posterior towards top, medial towards right); $C$ : right ulna in anterior view (proximal towards top); D: left radius in anterior view (proximal towards top); E: right femur in anterior view (proximal towards top); F: right tibia-fibula in anterior view (proximal towards top); G: caudal vertebrae in dorsal view and hemal arch in lateral view.

Scale bar equal $5 \mathrm{~cm}$. 

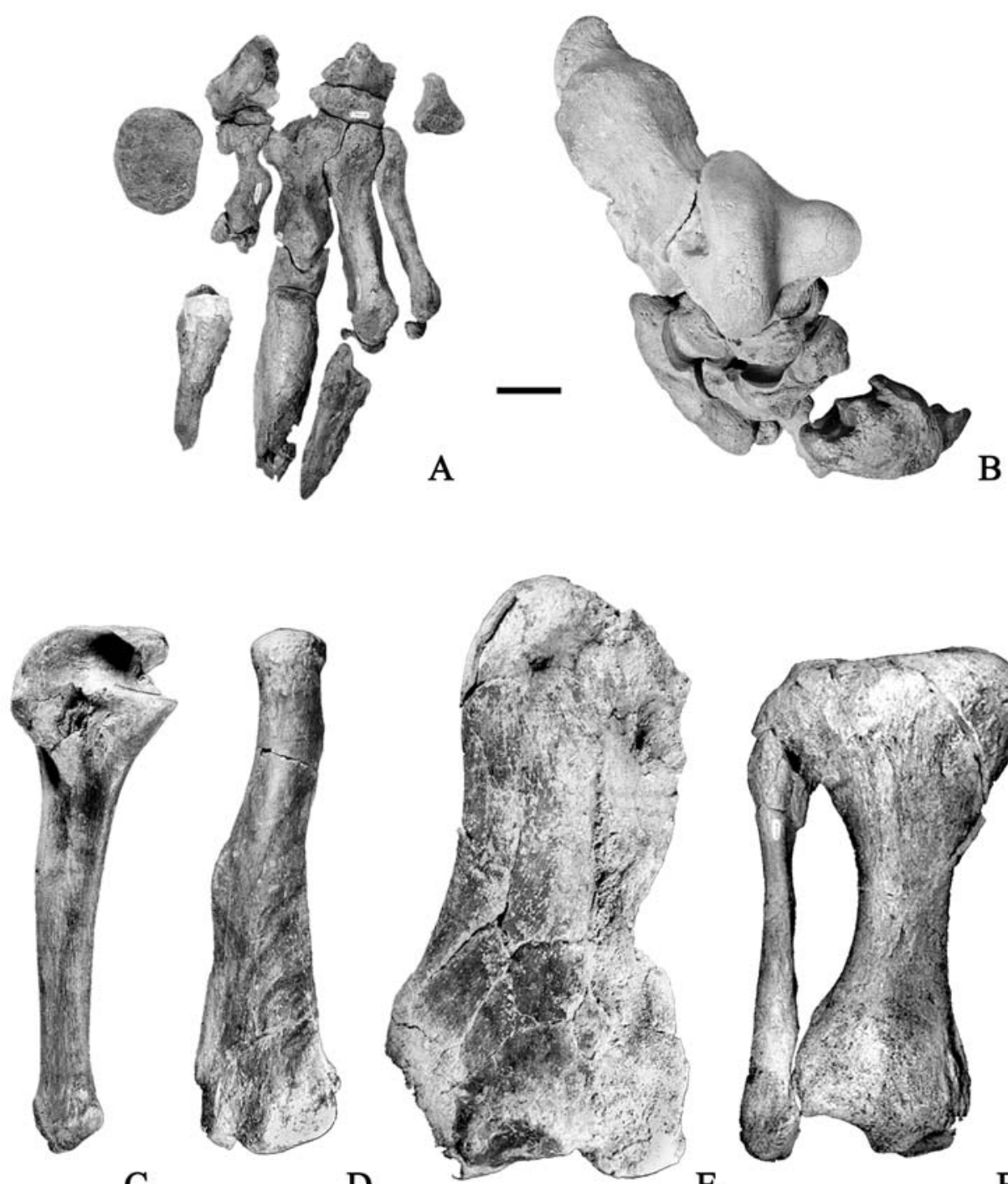

C

D
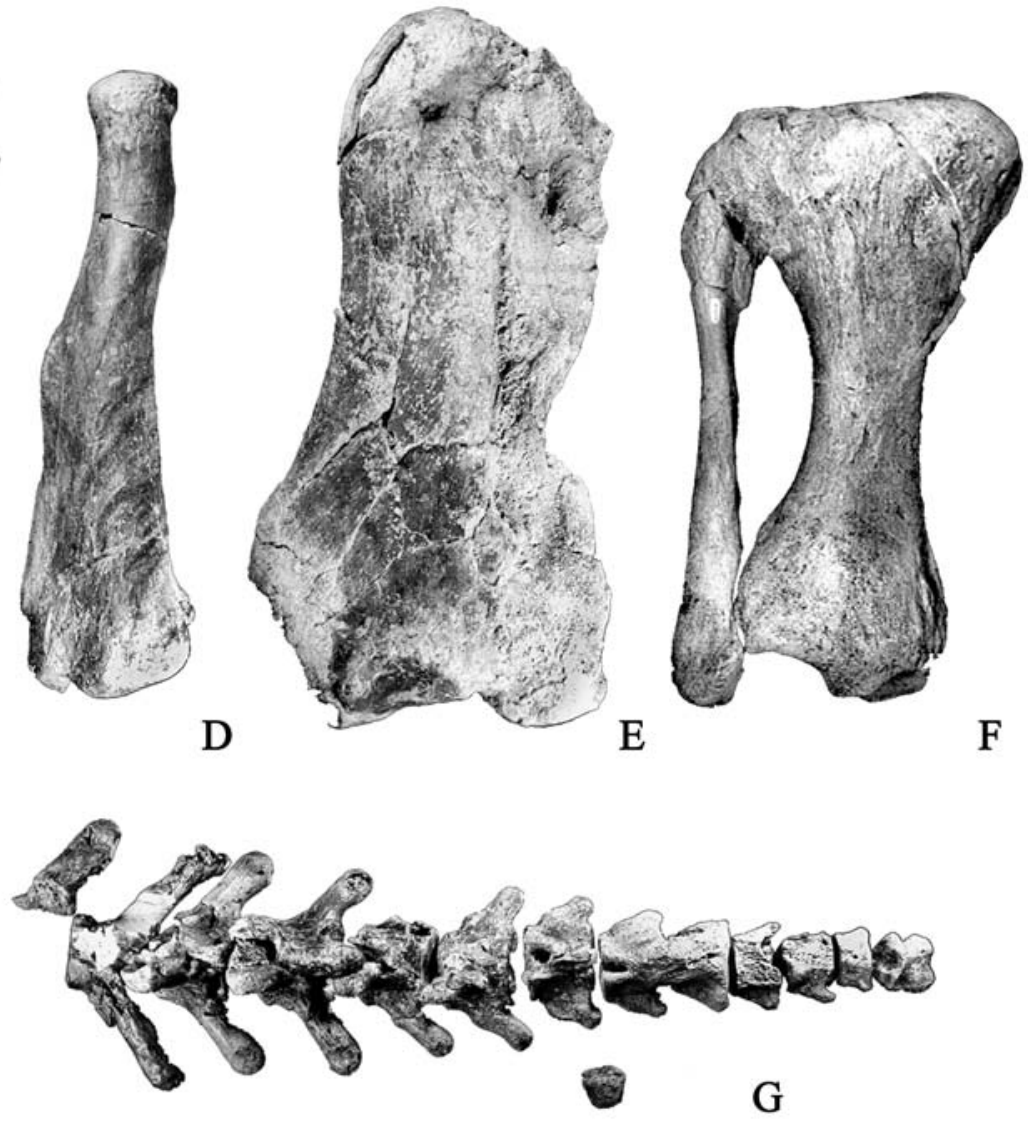
Fig. 9 - Megatherium (Pseudomegatherium) tarijense (UNI 1) from Yantac. A-B: skull in lateral and ventral views respectively (anterior towards right); C-D: mandible in lateral (reversed from the original) and occlusal views respectively (anterior towards right). Scale bar equals $5 \mathrm{~cm}$. 


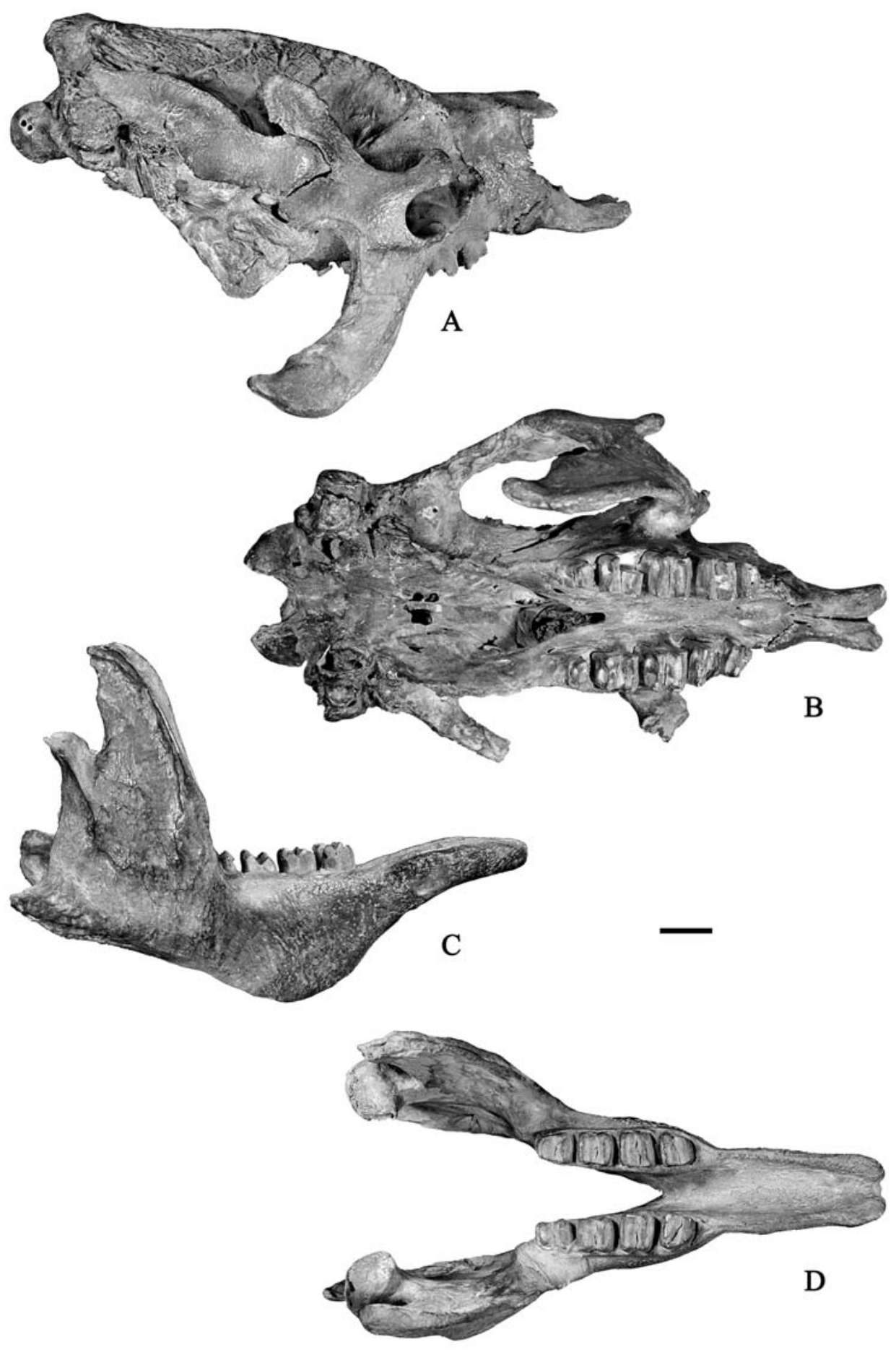


Fig. 10 - Megatherium (Pseudomegatherium) tarijense (UNI 1) from Yantac. A: right Mc III in dorsal view (proximal towards top); B: right humerus in posterior view (medial towards right); C-D: right femur in anterior (lateral towards left) and anterodistal (anterior towards top) views; $\mathrm{E}$ : pelvis in anterior view (dorsal towards top). Scale bars equals $5 \mathrm{~cm}$. 


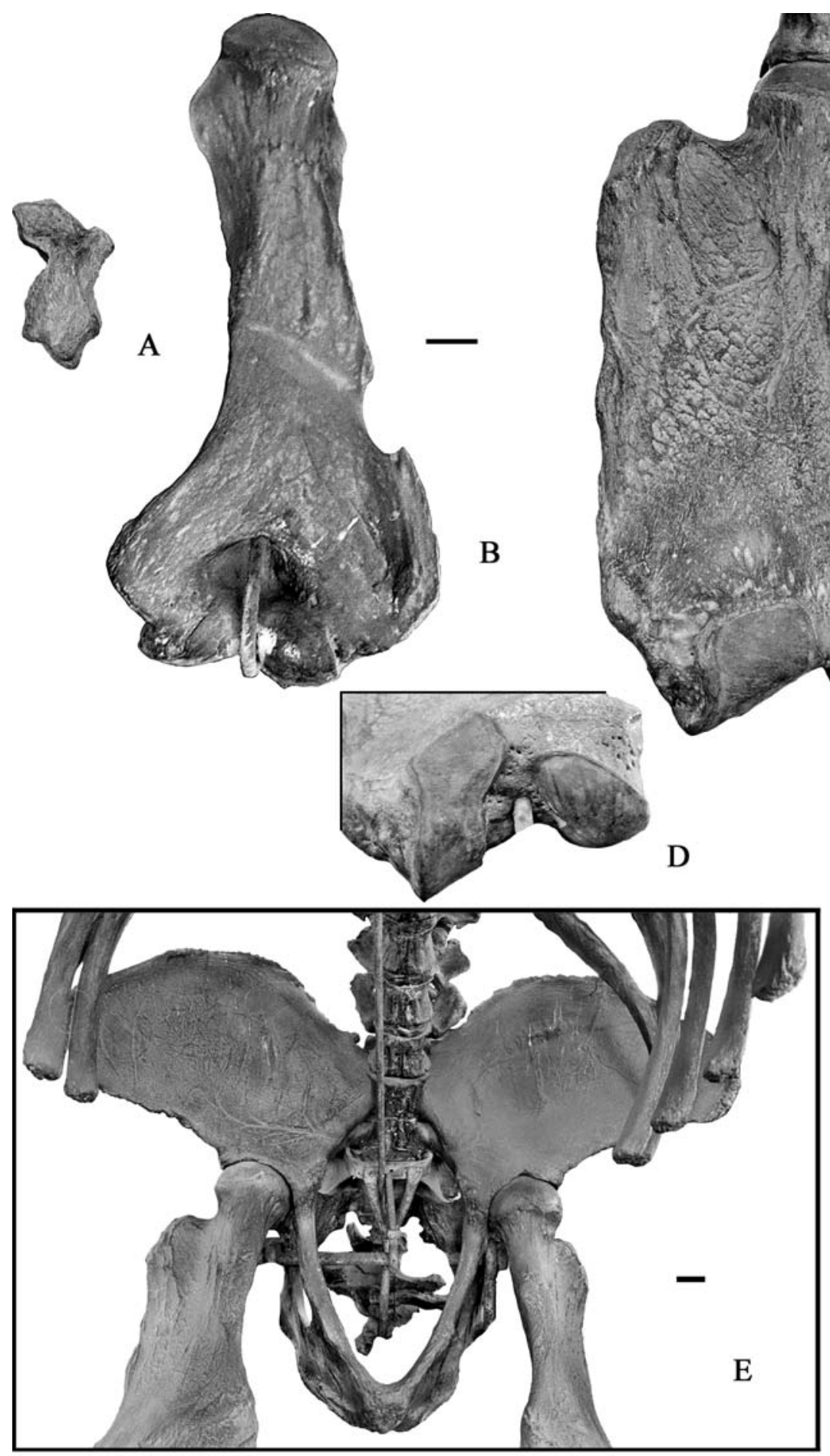


Fig. 11 - Left astragali of: cf. Eremotherium sp. (A, D, G: MUSM 22, reversed from the original) from Tarapoto; Megatherium (Pseudomegatherium) sp. nov. (B, E, H: MUSM 157) from Celendín; Megatherium (Pseudomegatherium) urbinai (C, F, I, MUSM 15) from Sacaco (Pujos \& Salas, 2004). All astragali are seen in anterior (AC: dorsal towards top, medial towards left), plantar (D-F: posterior towards top, medial towards right), and dorsolateral (G-I: posterior towards top, medial towards left) views. A-C: angle between the plan of the discoid and odontoid facets; D-F: extensions of the ectal facet and the sulcus tali; G-I: direction of the odontoid process, convexity of the discoid plan, and distance between discoid and ectal facets. Scale bar equals $5 \mathrm{~cm}$. 

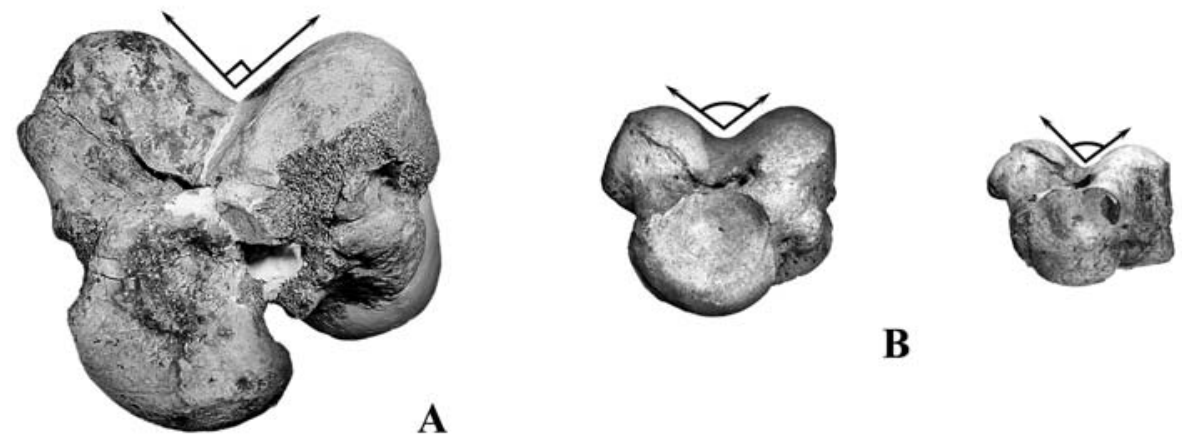

B

C

A
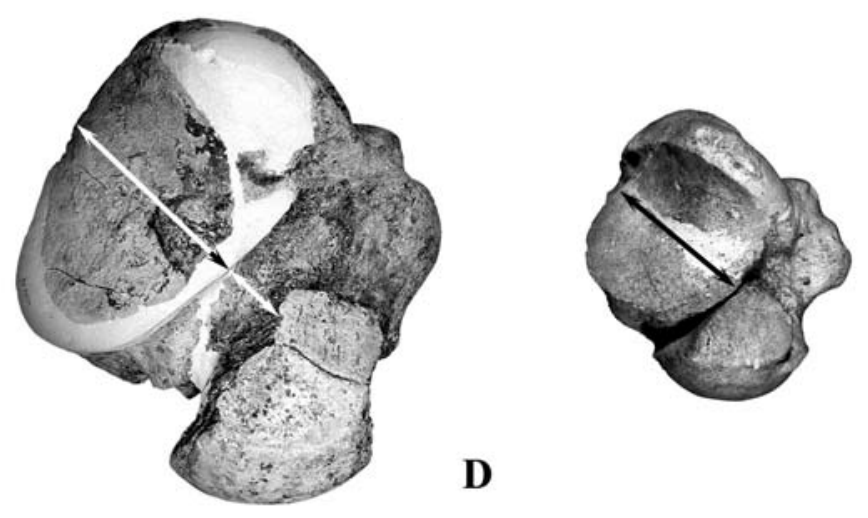

$\mathbf{E}$

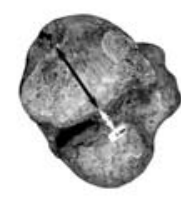

D
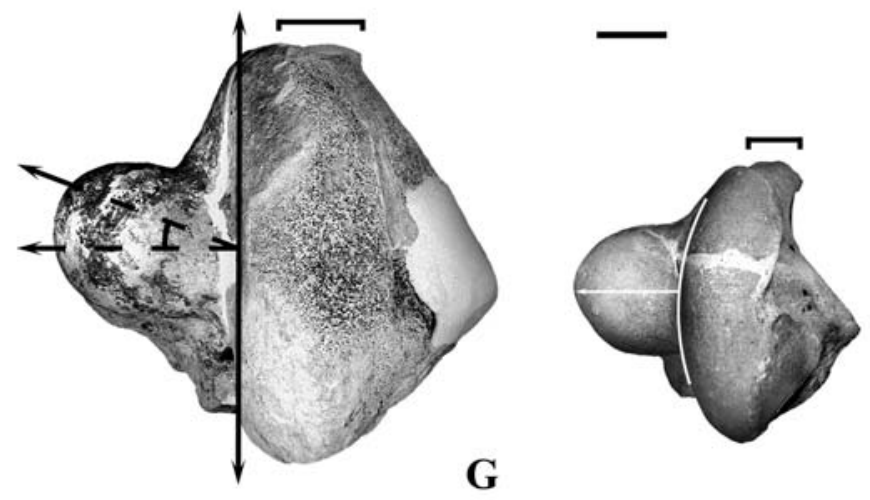

H

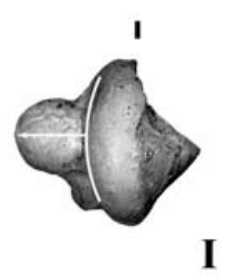

F G 